\title{
Impacts of the Brazilian innovation tax policy on the composition of private investments and on the type of innovation
}

\author{
Daniel Gama e Colombo* (D) https://orcid.org/0000-0002-0203-447X \\ Helio Nogueira da Cruz ** (iD https://orcid.org/0000-0002-3788-8520
}

Received: 21 January 2018 Revised version: 23 June 2018 Accepted: 29 June 2018

\section{ABSTRACT}

The objective of this paper is to investigate whether the tax incentives for innovation in Brazil established by Law 11,196/05 (BRASIL, 2005) have altered the composition of firms' innovation investments and their results. Based on the concept of behavioral additionality and on the design of the policy, we derive three propositions on how these incentives affect the bundle of innovation expenditures, the educational level of researchers and the type of innovation pursued by firms. Using disaggregate data at firm level from the Brazilian Industrial Innovation Survey (PINTEC) of 2008 and 2011 and other sources, the average treatment effect on the treated (ATT) is estimated through propensity score matching with differencein-differences. The main findings of the study are: (a) incentives had a positive impact on the research and development $(R \& D)$ intensity of innovation investments, increasing $R \& D$ spending by around 1,1 million Brazilian reais on average, while decreasing mean spending on acquisition of external knowledge and introduction of innovations in the market; (b) although the policy fostered additional hiring of researchers with undergraduate degree, no significant impact on personnel with master's or Ph.D. degrees was found; and (c) there is no evidence of impact on the balance between product and process innovation.

\footnotetext{
* Instituto Nacional de Estudos e Pesquisas Educacionais Anísio Teixeira (Inep), Brasília (DF), Brazil. E-mail: daniel.colombo@ inep.gov.br. At the time of this research, the author was a Ph.D. candidate at the School of Economics, Business and Accounting of the University of Sao Paulo (USP), Sao Paulo - SP, Brazil.

** Universidade de São Paulo (USP), São Paulo (SP), Brazil. E-mail: hncruz@usp.br.
} 
KeYwords | Behavioral Additionality; Private Innovation; Investment Composition; Tax incentives

JEL CODE | H25; H32; O38; O54

\section{Impactos da política fiscal de inovação brasileira na composição de investimentos privados e no tipo de inovação}

\section{Resumo}

O objetivo deste artigo é investigar se os incentivos fiscais para inovação da Lei 11.196/05 (BRASIL, 2005) alteraram a composição dos investimentos em inovação das empresas e seus resultados. Tomando por base o conceito de adicionalidade comportamental e o desenho da política fiscal, são apresentadas três proposições sobre como esses incentivos afetam a cesta de gastos com inovação, o nível educacional dos pesquisadores e o tipo de inovação desenvolvido pelas firmas. A partir de dados desagregados da Pesquisa de Inovação (PINTEC) de 2008 e 2011 e de outras fontes, o efeito médio do tratamento nas unidades tratadas (ATT) é estimado utilizando-se um pareamento por escore de propensão (PSM) com diferença-em-diferenças. As principais conclusões do estudo são: os incentivos impactaram positivamente a intensidade de pesquisa e desenvolvimento $(\mathrm{P} \& \mathrm{D})$ dos investimentos em inovação das firmas, elevando os gastos com $\mathrm{P} \& \mathrm{D}$ em cerca de $\mathrm{R} \$ 1,1$ milhão na média, assim como reduzindo os gastos médios com aquisição de outros conhecimentos externos e com introdução de inovações no mercado; embora a política tenha fomentado a contratação adicional de pesquisadores com diploma de graduação, não foi encontrado impacto significativo para pessoal de pesquisa com titulação de mestrado ou doutorado; e não há evidência de impacto no balanço entre inovaçóes de produto e processo.

PALAVRAS-CHAVE | Adicionalidade comportamental. Composição de Investimentos. Incentivos Fiscais. Inovação privada

Códigos-Jel | H25; H32; O38; O54 


\section{Introduction}

In 2005, the Brazilian government approved a new framework of tax incentives to promote business innovation in the country. Law 11,196/05 (BRASIL, 2005) established a horizontal policy that allowed for the enhanced deduction of innovation expenses from the taxable income of beneficiary firms, among other benefits. A group of studies found positive effects of these incentives on private innovation investment (KANNEBLEY JR. et al., 2013; KANNEBLEY JR.; SILVEIRA PORTO, 2012; SHIMADA, 2014), but up to this point there is no evidence on whether firms' innovation strategies were also affected. This paper addresses this issue by presenting a quantitative analysis of the impact of the tax incentives on the composition of the innovation investments and on the type of innovation pursued by beneficiary firms.

In the last decades, the economic literature on innovation policies has assessed and estimated the impact of government incentives in different countries, whether in the case of direct subsidies or tax incentives (CUNNINGHAM; GÖK; LARÉDO, 2012; KÖHLER; LAREDO; RAMMER, 2012). However, until recently, majority of studies considered research and development (R\&D) as a homogeneous activity (ZÚNIIGA-VICENTE et al., 2014) and did not investigate modifications in the composition of private spending caused by changes in firms' strategies and behavior - the 'behavioral additionality' effect (GEORGHIOU; CLARYSSE, 2006).

However, this is a relevant topic for innovation policy, as the composition of investments is likely to affect their efficiency and their results (AGGARWAL; HSU; WU, 2015; BARGE-GIL; LÓPEZ, 2014). For this reason, recent empirical analyses (discussed in section 2) have advanced this debate by assessing how innovation policy impacts the structure of firms' innovation bundles, although the existing evidence is still small (NEICU; TEIRLINCK; KELCHTERMANS, 2016).

This paper aims to contribute to this literature by presenting evidence of the Brazilian case. The objective is to investigate whether the tax incentives provided by Law 11,196/05 (BRASIL, 2005) have had an impact on the bundle of innovation investments of beneficiary firms and on their results. We consider three different criteria: (a) spending on $R \& D$ and other categories of innovative activities; $;^{1}$ (b) the educational level of R\&D personnel; and (c) the type of innovation (product or process). Based on the notion of behavioral additionality and on the policy design discussed in sections 2 and 3, we derive three propositions on how investments and results may have been affected by the policy. These propositions are tested 1 As defined in section 4 . 
through a quantitative investigation using disaggregate data at firm level of the Brazilian Industrial Innovation Survey (PINTEC). Our focus is not on the overall level of innovation inputs (or on their results), but rather on how the structure of the innovation bundle was affected by the incentives.

This paper presents the following contributions to the existing literature: first, it sheds new light on the impact of the tax incentives of Law 11,196/05 (BRASIL, 2005), whereas previous quantitative studies discussed in section 3 focused exclusively on input and output additionalities. Besides, to the best of our knowledge, it is the first quantitative assessment of the impact of a policy on the composition of private innovation investments in Brazil. Finally, as the empirical literature on this subject is still limited and refers almost exclusively to developed economies, this paper adds to the existing body of knowledge at the international level by presenting an analysis of the Brazilian case.

The following section reviews the literature on behavioral additionality of innovation policies and on the classifications used in the empirical analysis. Section 3 describes the innovation tax policy in place in Brazil, and section 4 presents the data and empirical strategy used for the analysis. The fifth part exhibits and debates the results, and the last section summarizes and concludes the paper.

\section{Literature review}

\subsection{The behavioral additionality of innovation policies}

The effect of public policies on innovation strategies of firms is known as the behavior additionality effect (BUISSERET; CAMERON; GEORGHIOU, 1995). Georghiou (1994, 2002) suggested that policy impact had three different dimensions: input (usually interpreted as expenditure increase); behavioral (change in the firm's strategy); and output (modification of results). The report of the Organization for Economic Co-operation and Development (OECD) on the subject stated that this approach aims to "measure explicitly changes in the ways firms conduct R\&D as a result of government policy instruments" (OECD, 2006, p. 7) regardless of a significant impact on the bulk of total R\&D. These analyses are supposed to complement (and not replace) the traditional approach of input additionality.

The importance of the behavioral approach lies in the fact that the traditional concepts of input and output additionality do not sufficiently describe the impact of public policies on the innovation process (FALK, 2007). The idea is to open 
the "R\&D black box" (DAVID; HALL; TOOLE, 2000) to identify the channels through which government subsidies and incentives alter private innovation. For this reason, this approach connects to a rationale for government intervention that goes beyond the neoclassical concept of market failure (GÖK; EDLER, 2012; NEICU et al., 2016). It comes closer to an evolutionary or neo-Schumpeterian perspective of innovation policy that emphasizes gains in the cognitive capacity and knowledge base of firms, to which their behavior and strategies are intrinsically linked $(\mathrm{BACH}$; MATT, 2002).

An interesting feature of behavioral additionality is that it comprises multiple layers, or dimensions, of firms' innovation strategies. For this reason it opens a wide range of subjects and methods that can be used for policy analysis and evaluation. ${ }^{2}$ A growing number of empirical studies have assessed behavioral additionality effects in distinct policies and contexts. According to Cunningham et al. (2012), most of this literature focused on collaboration and partnerships (BUSOM; FERNÁNDEZRIBAS, 2008) but there are also analyses on organizational learning (CLARYSSE; WRIGHT; MUSTAR, 2009); project enlargement and commercialization behavior (HSU; HORNG; HSUEH, 2009); duration of projects (FALK, 2007); risk of innovative activity (FELDMAN; KELLEY, 2003); and probability of exiting the market (EBERSBERGER, 2011).

The composition of innovation investments and their results may be deemed to be one of the perspectives used to analyze behavioral additionality. The assumption is that a change in firms' innovation strategies and activities also affects the allocation of their available resources. In this paper, the behavioral additionality of the Brazilian policy is assessed using three dimensions or groups of variables: the division of investment in different innovative activities; the educational background of R\&D personnel; and the balance between product and process innovation.

The main point of investigating the first (composition of the bundle of innovative activities) is to acknowledge and consider that firms choose between distinct activities to obtain and apply new information in order to increase productivity or design new products. In this conceptual framework, R\&D is but one strategy available to the firm. The Frascati Manual requires that, to fall under the category of R\&D, the activity must be (a) novel, (b) creative, (c) uncertain, (d) systematic, and (e) either transferable or reproducible (OECD, 2015a). Innovative activity, on the other hand, is a broader concept that includes any procedure aimed

2 For a review of the literature, see Gök and Edler (2012) and Cunningham et al. (2012). 
at implementing innovation, whether of a scientific, technological, organizational, financial, or commercial nature (OECD, 2005).

The behavioral additionality in this case can be described as a change in the relative importance of each activity in the innovation strategy of the firm. It refers to the 'knowledge acquisition' dimension of the government support, or how firms organize their innovation activities (GEORGHIOU; CLARYSSE, 2006). A reduction in the share of strict $R \& D$ indicate that firms favor lower risk projects with less technical complexity (PINGFANG; WEIMIN; LUNDIN, 2006) and greater short-run profit prospects (DAVID et al., 2000). We argue that such an effect can be assessed by investigating how the policy affects the spending on each category of innovative activity, or the composition of the investment bundle. The composition of investments was used by Neicu et al. (2016) to measure and assess behavioral additionality (although the authors focus on the research versus development ratio); Hsu et al. (2009) and Feldman and Kelley (2003) also considered additional investment in risky projects as an indicator of policy-induced change in firms' behavior.

Empirical studies found that firms commonly undertake more 'strict R\&D' when they benefit from direct subsidies (CLAUSEN, 2009; PINGFANG et al., 2006). Feldman and Kelley (2003) and Neicu et al. (2016) also found evidence that government support might favor high-risk research. Pingfang et al. (2006), on the other hand, concluded that enterprises tend to switch from R\&D to low-tech activities, which produce quicker results in the short run.

The second classification analyzed in this paper is the educational level of R\&D personnel. The upgrade of human resources is another dimension of behavioral additionality described by Georghiou and Clarysse (2006), Clarysse, Bilsen, Steurs, and Consult (2006), Hsu et al. (2009) and Suzuki and Yumitori (2006). It is considered a key component of this approach (AFCHA; GARCÍA-QUEVEDO, 2016) as the proper qualification of personnel is deemed essential for the development of innovation-related projects (DUMONT; SPITHOVEN; TEIRLINCK, 2015; SPITHOVEN; TEIRLINCK, 2010), particularly when considering the complexity of these activities and the fact that they rely heavily on the knowledge of available research personnel. Based on this argument, innovation policies should aim not only at increasing the number of researchers hired, but also at improving the qualifications or educational level of the R\&D team, thus enabling the firm to acquire new skills and competitive advantages (AFCHA; GARCÍA-QUEVEDO, 2016). 
A small number of empirical studies has investigated the impact of innovation policies on the educational level of R\&D personnel. According to Clausen (2009) and Dumont et al. (2015), the effect is positive for distinct public incentives, and both studies found that beneficiary firms hired more highly qualified researchers, with either a master's or a Ph.D. degree. Afcha and García-Quevedo (2016), on the contrary, did not obtain any significant result for the educational mix of research personnel.

The third classification considered herein distinguishes whether firms pursue product or process innovation (ARALICA; BOTRIĆ, 2013; BELADI, MARJIT; YANG, 2012; SAHA, 1999). Such a distinction was used by Hyvärinen (2006) to assess the behavioral additionality of public funding in Finland. Both types can positively impact a firm's output, but process innovation is more related to productivity increase, while product innovation generates either new or betterquality goods (SAHA, 1999). However, it is not uncommon or these two types of innovation to be closely linked. The objective of considering these categories in a behavioral additionality analysis is to assess whether the innovation policy has had any role or influence on the type of R\&D pursued by firms, or if this was the result of other factors, such as industrial sector, firm size, and market structure (COHEN; KLEPPER, 1996). Empirical evidence on the topic is ambiguous. Aralica and Botrić (2013) found that only product innovation benefited from innovation policies in Croatia, while according to Jaffe and Le (2015), New Zealand firms increased their results in both types at similar rates.

\subsection{Tax incentives and behavioral additionality}

The choice of policy instrument can affect the type and magnitude of behavioral additionality, as distinct requirements, obligations, incentivized activities and funding schemes can trigger different responses and behaviors from firms. Understanding such differences is relevant for improving both the policy design and the innovation policy mix (GEORGHIOU; CLARYSSE, 2006). In this study, we focus on the case of tax incentives, a policy tool to foster innovation that has been adopted by a growing number of countries since the 1980s (BLOOM et al., 2002).

There are two main arguments to maintain that tax incentives should present different behavioral additionality effects from those arising from direct subsidies. The first one is that fiscal benefits are considered more market-oriented, meaning that 
firms retain the decision on which projects and ideas are financed and implemented, instead of a previous choice by government bureaucracy (DAVID et al., 2000; HALL; VAN REENEN, 2000). By keeping the decision-making process within the firm, these incentives minimize inefficiencies and the allocative distortions arising from government intervention. On the other hand, tax incentives may pose a problem in terms of the social returns of funded projects. Pursuant to the market failure argument, innovation policies are mainly justified by the high levels of positive externalities or knowledge spillovers (CUNNINGHAM et al., 2012). However, as tax incentivized firms retain full control of their R\&D portfolio, they would minimize such externalities by developing technologies that can be largely appropriated by means of internalized profits (HALL; VAN REENEN, 2000).

Both the market-oriented nature and bias towards projects with less knowledge spillovers should impact the nature of R\&D performed by firms, thus providing a theoretical basis to investigate the behavioral additionality of tax incentives. However, the empirical literature provides limited information on this topic, as most studies on tax incentives focus on input additionality (ZÚNIIGA-VICENTE et al., 2014). The elasticity of fiscal benefits was the object of different analyses, ${ }^{3}$ and the majority of them identified an elasticity inferior to one (IFS, 2015), although there is evidence that these effects tend to increase with time (KÖHLER et al., 2012).

Most studies on behavioral additionality mentioned in the last section did not focus on fiscal incentives. As mentioned, in spite of recent developments, there is still little evidence on how tax breaks affect behavioral additionality and innovation investment composition. Four studies are noteworthy as they considered the impact of fiscal measures in at least one of the dimensions considered herein (ARALICA; BOTRIĆ, 2013; DUMONT et al., 2015; NEICU et al., 2016; PINGFANG et al., 2006). In all cases, they found different policy effects for individual categories of investment or type of innovation, suggesting a change in firms' innovation strategies or behavior induced by government support.

Clausen (2009) argued that the impact of subsidies on investment composition is inherently linked to the level of uncertainty of subsidized projects and, for this reason, the policy design must be taken into account when analyzing the potential effect of a subsidy scheme. We follow this reasoning and examine the design of the tax incentives approved by the Brazilian government to develop the hypotheses of such impacts.

3 For recent reviews of this literature, see IFS (2015) and Ladinska, Non and Straathof (2015). 


\section{The Brazilian innovation tax policy}

Since 2003, Brazil has experienced a substantial shift in the industrial policy paradigm at the federal level. Fostering economic development has become a primary policy target to be achieved by nurturing dynamic comparative advantages and competitiveness of national companies at the international level. Such was the message of the Industrial, Technology, and Foreign Trade Policy announced by the government in 2003 (BRAZIL, 2003).

A new regulatory framework for innovation tax incentives was approved by Brazilian Congress in 2005. Following the experience and framework of other countries (OECD, 2015c), the new Law 11,196/05 (BRASIL, 2005) expanded previous incentives and reduced the cost of innovation projects by allowing the deduction of expenditures from the base of income taxes. Along with other sectoral and regional policies, the incentives raised the volume of tax benefits to corporate R\&D substantially. The Brazilian 'b-index' (an indicator used by the OECD to measure the tax cost of $\mathrm{R} \& \mathrm{D}$ and innovation activities $)^{4}$ decreased around $8 \%$, reaching a value of around 0.73 (ARAÚJO, 2010). This represents a considerably lower cost than the one observed in most OECD countries, that averaged a 'b-index' of 0.88 in 2011, although it is still higher than the estimate for countries like France (0.66), Portugal (0.59) and Spain (0.65) (WARDA, 2013).

The law also represented an important change in the structure of the national innovation policy mix. The share of public support for R\&D through tax incentives grew from less than a quarter in 2002 to more than $40 \%$ in 2008, later declining to around a third of total benefits (BRASIL, 2016b). The same trend has been observed in different countries since the last decade, as budgetary constraints led governments to favor policies that do not affect their expenditures, such as tax incentives (OECD, 2016).

Law 11,196/05 (BRASIL, 2005) initially provided for six tax incentives, but further amendments added others and modified existing ones. Considering the focus of this study on the composition of investments and results, Table 1 classifies these benefits according to the changes they introduce in the relative tax cost of different activities or categories, with potential impact on firms' innovation strategies and investment composition, thus justifying our choice of the three criteria described in the previous section and providing the basis for the propositions to be tested in the empirical study.

\footnotetext{
4 "The b-index is a measure of the level of pre-tax profit a 'representative' company needs to generate to break even on a marginal, unitary outlay on R\&D” (OECD, 2013, p. 1).
} 
TABLE 1

Summary of the tax incentives of Law 11,196/05

\begin{tabular}{|c|c|c|c|c|}
\hline $\begin{array}{c}\text { Broad } \\
\text { classification }\end{array}$ & $\begin{array}{l}\text { Incentivized activ- } \\
\text { ity or category }\end{array}$ & Applicable tax & Incentive & $\begin{array}{l}\text { Incentive rate or } \\
\text { ceiling }\end{array}$ \\
\hline $\begin{array}{l}\text { R\&D and other } \\
\text { innovative activities }\end{array}$ & R\&D expenditures & $\begin{array}{l}\text { Income tax; } \\
\text { CSLL }^{2}\end{array}$ & Tax deduction & $\begin{array}{l}\text { Up to } 160 \% \text { of } \\
\text { expenditures }\end{array}$ \\
\hline $\begin{array}{l}\text { Educational } \\
\text { Level of R\&D } \\
\text { personnel }\end{array}$ & $\begin{array}{l}\text { Hiring new re- } \\
\text { search personnel } \\
\text { (up to 5\%) }\end{array}$ & $\begin{array}{l}\text { Income tax; } \\
\text { CSLL }^{2}\end{array}$ & Tax deduction & $\begin{array}{l}\text { Up to } 20 \% \text { addi- } \\
\text { tional deduction of } \\
\text { R\&D expendituresb }\end{array}$ \\
\hline \multirow{2}{*}{$\begin{array}{l}\text { Type of } \\
\text { innovation }\end{array}$} & $\begin{array}{l}\text { R\&D expenditures } \\
\text { related to valid } \\
\text { patent }\end{array}$ & $\begin{array}{l}\text { IIncome tax; } \\
\text { CSLL }^{a}\end{array}$ & $\begin{array}{l}\text { Additional tax } \\
\text { deduction }\end{array}$ & $\begin{array}{l}\text { Additional } 20 \% \\
\text { deduction of R\&D } \\
\text { expenditures }\end{array}$ \\
\hline & $\begin{array}{l}\text { Filing of patents } \\
\text { and trademarks } \\
\text { abroad }\end{array}$ & $\begin{array}{l}\text { Withholding in- } \\
\text { come tax }\end{array}$ & Tax reduction & Total exemption \\
\hline \multirow{5}{*}{$\begin{array}{l}\text { Other } \\
\text { incentives }\end{array}$} & New equipment & Income tax; CSLL $^{2}$ & $\begin{array}{l}\text { Accelerated depre- } \\
\text { ciation }\end{array}$ & $\begin{array}{l}\text { Full depreciation in } \\
\text { the first year }\end{array}$ \\
\hline & New equipment & $\mathrm{IPI}^{\mathrm{b}}$ & Tax reduction & $50 \%$ of the tax \\
\hline & Other capital goods & Income tax & Tax deduction & $\begin{array}{l}\text { Deduction of non- } \\
\text { depreciated capital }\end{array}$ \\
\hline & Intangible goods & Income tax & $\begin{array}{l}\text { Accelerated amor- } \\
\text { tization }\end{array}$ & $\begin{array}{l}\text { Full amortization } \\
\text { in the first year }\end{array}$ \\
\hline & $\begin{array}{l}\text { Innovation out- } \\
\text { sourcing to non- } \\
\text { profit research } \\
\text { institutes }\end{array}$ & Income tax; CSLL ${ }^{a}$ & Tax deduction & $\begin{array}{l}50 \% \text { to } 250 \% \text { of } \\
\text { expenditures }\end{array}$ \\
\hline
\end{tabular}

Source: 11,196/05 (BRASIL, 2005).

${ }^{a}$ CSLL - Social Contribution to Net Profit.

${ }^{\mathrm{b}}$ Tax on industrialized products.

Deduction of $\mathrm{R} \& \mathrm{D}$ expenditures is the most important incentive and it represents almost the entire value of tax breaks provided by the law (BRASIL, 2016a). Firms can deduct up to $160 \%$ of their 'technological research and technological innovation development' spending from the taxable base of income tax and social contribution to the net profit. In principle, this benefit favors the development of strict R\&D projects over other innovative activities. However, the conceptual framework of the policy blurs the distinction between R\&D and other innovative activities, as incentivized expenditures encompass not only the standard cases of research and experimental development, but also other activities that are classified as 'other types of innovative activities' (OECD, 2005). These include: (a) testing, standardization, calibration of machinery and equipment, and certification (labeled as 'industrial basic technology'); and (b) technical support services, including 
installation and maintenance of research equipment and facilities, and training of research personnel.

If, in addition to the R\&D spending, the firm increases its research payroll, the ceiling of expense deductions rises by $20 \%$ of total spending. The law neither distinguishes nor sets any requirement for minimum academic degrees or experience of newly hired research personnel. Decree 5,798/05 defines researcher as any graduate, undergraduate, or technical high school level employee dedicated to R\&D activities.

The law also makes no distinction between product and process innovation as both are included in the definition of technological innovation and are, therefore, eligible for the incentives. Nonetheless, there is an additional benefit for expenditures related to patented technologies, and firms are exempt from withholding income tax levied on payments for patent filing abroad. As there is evidence in the literature that patents are more suited to the protection of products than of process innovation (LÓPEZ, 2009), one may argue that these provisions create a distinction in favor of the former type.

Thus far, only a few studies have tried to assess the impact of tax incentives for innovation in the country. Three quantitative analyses concluded that they had positive effects on firms' R\&D expenditures, technical personnel and export levels (KANNEBLEY JR. et al., 2013; KANNEBLEY JR.; SILVEIRA PORTO, 2012; SHIMADA, 2014). None of these analyses have considered either the behavioral additionality effects of the policy or how it has affected either the mix of activities or input factors for innovation. This is the main novelty and purpose of the empirical analysis that follows.

\section{Empirical analysis}

This empirical study aims to investigate the impact of the tax incentives of Law 11,196/05 (BRASIL, 2005) on the composition of the innovation investments of beneficiary firms and their results, in order to assess the behavioral additionality of the policy. The main assumption, as mentioned, is that the bundle of investments and results reflects the choices and strategies of firms, and that a change in its composition indicates a behavioral additionality of the tax benefits. Such change is assessed herein by estimating the impact of the policy on the individual components of the three broad classifications discussed in the previous sections, and then comparing the individual results. 
Following Clausen (2009), we understand that such effect can only be properly explained by taking into account the policy design, along with the economic theory presented in section 2. Based on such discussions, three propositions for the impact of the tax incentives are presented and tested herein:

$1^{\text {st }}$ Proposition: the incentives caused beneficiary firms to increase the $R \& D$ intensity of their investment bundle, spending a larger portion of its innovation spending with strict $R \& D$. As discussed in section 2, this proposition refers to the 'knowledge acquisition' dimension of the policy. It states that firms that benefited from the incentives are likely to invest a substantial part of the additional resources in R\&D, thus developing riskier and more technologically complex projects. Such a hypothesis follows from the result of previous empirical analyses (CLAUSEN, 2009; NEICU et al., 2016; PINGFANG et al., 2006) and can also be explained by the fact that strict R\&D is the main category of expenditure that can be deducted from a firm's taxable base - the most important incentive provided by the law.

$2^{\text {nd }}$ Proposition: the policy had a positive effect on the educational level of the research team, but the impact on the hiring of highly qualified researchers is not significant. Again, previous studies suggested that government support should positively affect the composition of research personnel in terms of their educational background (AFCHA; GARCÍA-QUEVEDO, 2016; CLAUSEN, 2009; DUMONT et al., 2015). However, as the Brazilian law does not require beneficiary firms to hire researchers with high qualifications (graduate degrees), companies with no projects that require professionals with such advanced knowledge should find it more advantageous to employ less qualified - and less expensive - personnel to obtain the additional incentives described in Table 1. For this reason, we expect a non-significant effect on the number of researchers with masters and Ph.D. degrees, which implies a limited impact of the policy on the improvement of firms' innovative capacity (AFCHA; GARCÍA-QUEVEDO, 2016).

$3^{\text {rd }}$ Proposition: the policy did not significantly impact the balance between product and process innovation in beneficiary firms. Although the policy provides for additional incentives that are more appropriate for product innovation, we do not expect a significant change in the type of innovation pursued by incentivized companies, mostly because of the relative small size of the additional deduction for valid patents, and also due to a complementarity effect between the two types of innovation (LIN; SAGGI, 2002). 


\subsection{Identification strategy}

The research strategy implemented is the propensity score matching (PSM) (DEHEJIA; WAHBA, 1999, 2002). The main rationale of this method is to estimate the causal effect of treatment (the innovation tax incentives) by comparing the value of outcome variables for treated units (beneficiary firms) with an estimated value of such variables had such units not been treated - the average treatment effect on the treated (ATT). The comparison between supported and unsupported firms is one of the main frameworks used to the assess behavioral additionality of innovation programs (FALK, 2007).

Firms in the control group (non-treated observations) are used as a basis for such estimation, but as the incentives are not randomly assigned, the expected value of outcome variables conditional on treatment for these firms is likely to be different from the value for firms in the treated group - the selection bias problem (DEHEJIA; WAHBA, 2002). To account for these differences, the PSM uses a preliminary step in which firms from both groups are matched based on their probability of obtaining the incentives.

Such probability for a firm (i) is represented by a propensity score calculated using a set of covariates and applying a logit functional distribution form. As the sample of firms and the year of participation in the policy considered for the analyses change for each broad classification (as explained in section 4.2), a specific propensity score is estimated for each case, so it more appropriately reflects the probability of treatment for that group.

The crucial assumption of the model is the 'conditional independence' or 'selection on observables', meaning that, once the propensity score is controlled for, participation in the policy $\left(T_{i}=1\right.$ if firm ' $i$ ' benefited from the incentives, and $T_{i}$ $=0$ if not) can be deemed to be random. If such assumption holds, the expected conditional values of outcome variables for treated $\left(E\left[Y_{i 0} \mid p\left(X_{i}\right), T_{i}=1\right]\right)$ and nontreated $\left(E\left[Y_{i 0} \mid p\left(X_{i}\right), T_{i}=0\right]\right)$ firms are independent of treatment, and therefore they can be considered equivalent. The selected control group can then be used as a suitable counterfactual for estimation of the ATT.

$$
Y_{i 0} \Perp T_{i} \mid p\left(X_{i}\right) \Rightarrow E\left[Y_{i 0} \mid p\left(X_{i}\right), T_{i}=0\right]=E\left[Y_{i 0} \mid p\left(X_{i}\right), T_{i}=1\right]
$$


In practical terms, after excluding observations out of the common support, ${ }^{5}$ treated units were matched with their control counterparts using the nearest neighbor with replacement algorithm. A means test is used to assess the quality of matching, checking if covariates are reasonably balanced between matched units.

The ATT for non-binary outcome variables (categories of innovative activities and educational level of R\&D personnel) is calculated through linear regression with matched units using the difference between the values after $\left(Y_{i T}^{1}\right)$ and before $\left(Y_{i T}^{0}\right)$ treatment effect took place, as presented in equation 2. This difference-in-differences framework weakens the conditional independence assumption for it allows timeinvariant non-observable factors to influence treatment assignment probability, since they are excluded from the estimation as fixed effects. To assess the significance of the estimated ATT, we use Abadie and Imbens' (2006) heteroskedasticity-consistent analytical standard errors with two neighbors.

$$
\left.\tau\right|_{T=1}=E\left[Y_{i 1}^{1}-Y_{i 1}^{0} \mid p\left(X_{i}\right), T_{i}=1\right]-E\left[Y_{i 0}^{1}-Y_{i 0}^{0} \mid p\left(X_{i}\right), T_{i}=0\right]
$$

In the case of binary outcome variables, the ATT represents the impact of the incentives on the chances of a firm having developed product-only, process-only or both types of innovation in the 2009-2011 period. For this reason, the parameter is estimated through a logistic regression with a maximum likelihood estimator, using exclusively the units selected in the propensity score and weighting the control observations in the case of repetition.

The Rosenbaum bounds approach (DIPRETE; GANGL, 2004; ROSENBAUM, 2012) is applied to assess the sensitivity of statistically significant results to hidden variable bias, with $(\Gamma)$ intervals of (0.1) applied up to the value of two. As robustness checks, policy impact is estimated according to three different methods: (a) with log-linearized transformations of continuous outcome variables; (b) with two alternative matching algorithms (kernel and radius matching); and (c) through a Seemingly Unrelated Regression (SUR) framework for non-binary outcome variables (innovative activities and R\&D personnel) and through linear regression for binary type of innovation outcomes. 


\subsection{Data and descriptive statistics}

To generate the dataset used in this study, firm level data from the PINTEC surveys of 2008 and $2011^{6}$ (IBGE, 2010, 2013) were merged both with the list of beneficiary firms of Law 11,196/05 (BRASIL, 2005) disclosed annually by the Ministry of Science, Technology, Innovations and Communications (MCTIC) and with the list of exporting and importing firms disclosed by the Ministry of Development, Industry, and Foreign Trade (BRASIL, s.d.). The resulting dataset was organized in a panel format with two periods $(t=2008,2011)$. Nominal 2008 values were adjusted for inflation to 2011 using the IGP-DI index.

To reduce the heterogeneity of firms, only those that innovated in the 20092011 period were considered. Additionally, samples used in each analysis were narrowed, considering the particularities of each group of outcome variables: in the analysis of distinct innovative activities, only firms with positive spending in at least one of the categories in 2011 were considered; for the study of the educational level of research personnel, firms were required to have had positive R\&D spending in 2011 (as the salaries of these employees are classified as R\&D).

To ensure the baseline and final values of the non-dummy outcome variables are not biased for the difference-in-differences estimation, it was further necessary to exclude from the dataset (a) all firms that benefited from the tax incentives before the baseline year (2008), and (b) all firms that did not benefit from the tax incentives at the specific year considered for analysis, but that did at any other point in time. In the case of different categories of innovation activities and educational level of personnel, as treatment impacts the outcome variables at the same period, it was also necessary to ignore all firms from the control group that accessed the benefits in 2008 .

Participation in the policy is considered to be a treatment binary dummy variable. For the analysis of different categories of innovation activities and educational levels of personnel, tax incentives are assumed to affect innovation investments in the same year that companies benefited from them (2011). Observations in 2008 provide the baseline values to analyze the evolution of outcome variables in a difference-in-differences framework.

In the case of product and process innovation, however, the impact is estimated not for inputs but for results of these investments and, for this reason, it is necessary to consider a maturation period. In the PINTEC survey, firms state whether they have achieved any product or process innovation within the last three years. Such 6 The latest editions available when estimates were calculated. 
interval is used to assess the effect of incentives on the type of innovation pursued by firms. The year of participation in the policy considered for this analysis is 2008, and outcome is observed in 2009-2011, following the recommendation of the European Commission (2015) to access innovation output up to ' $t+3$ '.

TABLE 2

Descriptive statistics of outcome variables

\begin{tabular}{|c|c|c|c|c|c|c|}
\hline \multirow{2}{*}{$\begin{array}{c}\text { Broad } \\
\text { classification }\end{array}$} & \multirow{2}{*}{$\begin{array}{l}\text { Outcome } \\
\text { variable }\end{array}$} & \multirow{2}{*}{ Unit } & \multicolumn{4}{|c|}{ Descriptive statistics } \\
\hline & & & Treatment & $\mathbf{N}$ & Mean & Std. err. \\
\hline \multirow{14}{*}{$\begin{array}{l}\text { Innovative } \\
\text { activities }\end{array}$} & \multirow{2}{*}{$r d \_t o t$} & \multirow{14}{*}{$\begin{array}{l}\text { Brazilian } \\
\mathrm{R} \$ 1,000\end{array}$} & 0 & 6,412 & 290.46 & $15,562.81$ \\
\hline & & & 1 & 260 & 2675.66 & $20,468.64$ \\
\hline & \multirow{2}{*}{ knowledge } & & 0 & 6,412 & 12.82 & $1,673.42$ \\
\hline & & & 1 & 260 & -103.33 & 733.51 \\
\hline & \multirow{2}{*}{ software } & & 0 & 6,412 & 2.37 & $4,898.28$ \\
\hline & & & 1 & 260 & -166.27 & $1,380.23$ \\
\hline & \multirow{2}{*}{ machinery } & & 0 & 6,412 & 48.14 & $39,610.41$ \\
\hline & & & 1 & 260 & -1515.65 & $18,866.47$ \\
\hline & \multirow{2}{*}{ training } & & 0 & 6,412 & -14.55 & 579.13 \\
\hline & & & 1 & 260 & -3.63 & 876.80 \\
\hline & \multirow{2}{*}{ intro } & & 0 & 6,412 & -0.72 & $4,281.54$ \\
\hline & & & 1 & 260 & -637.62 & $5,240.06$ \\
\hline & \multirow{2}{*}{ project } & & 0 & 6,412 & 5.40 & $6,736.65$ \\
\hline & & & 1 & 260 & -1758.34 & $19,849.95$ \\
\hline \multirow{10}{*}{$\begin{array}{l}\text { Educational } \\
\text { level of R\&D } \\
\text { personnel }\end{array}$} & \multirow{2}{*}{ phd } & \multirow{10}{*}{$\begin{array}{l}\text { Number of } \\
\text { researchers }\end{array}$} & 0 & 6,412 & 0.18 & 13.58 \\
\hline & & & 1 & 260 & 0.11 & 2.42 \\
\hline & \multirow{2}{*}{ master } & & 0 & 6,412 & 0.09 & 5.92 \\
\hline & & & 1 & 260 & 0.20 & 2.80 \\
\hline & \multirow{2}{*}{ undergrad } & & 0 & 6,412 & 1.13 & 45.55 \\
\hline & & & 1 & 260 & 6.70 & 25.30 \\
\hline & \multirow{2}{*}{ high } & & 0 & 6,412 & 0.20 & 8.46 \\
\hline & & & 1 & 260 & 2.53 & 14.11 \\
\hline & \multirow{2}{*}{ others } & & 0 & 6,412 & -0.11 & 9.30 \\
\hline & & & 1 & 260 & 0.38 & 4.29 \\
\hline \multirow{6}{*}{$\begin{array}{l}\text { Type of } \\
\text { innovation }\end{array}$} & \multirow[t]{2}{*}{ product } & \multirow{6}{*}{ Binary } & 0 & 5,901 & 0.13 & 0.33 \\
\hline & & & 1 & 151 & 0.14 & 0.35 \\
\hline & \multirow{2}{*}{ process } & & 0 & 5,901 & 0.42 & 0.49 \\
\hline & & & 1 & 151 & 0.19 & 0.39 \\
\hline & \multirow{2}{*}{ both } & & 0 & 5,901 & 0.45 & 0.50 \\
\hline & & & 1 & 151 & 0.68 & 0.47 \\
\hline
\end{tabular}

Source: IBGE (2010, 2013. confidential microdata).

Note: With the exception of dummy variables for type of innovation, all variables represent the difference between real values in 2011 and 2008. Descriptive statistics calculated using all observations in the dataset. Nominal 2008 values were adjusted for inflation to 2011 using the IGP-DI index. 
The outcome variables used in this study are the categories or components of the three broad classifications mentioned previously. Their definitions are presented in Table A.1 of the Supplementary Material, and the descriptive statistics are displayed in Table 2. In addition, Figures 1 to 3 depict the average share of each innovative activity expenditure, ${ }^{7}$ researcher's degree and type of innovation in 2011. In the case of innovative activities and education levels of R\&D personnel, variables represent the difference between the 2011 and 2008 values, as suggested by the differencein-difference analysis. ${ }^{8}$ For the type of innovation, outcome variables are dummies that take the value of one if a firm succeeded in either product innovation, process innovation, or both types between 2009 and 2011.

FIGURE 1

Average share of spending on each innovative activity in 2011 for treatment and control groups

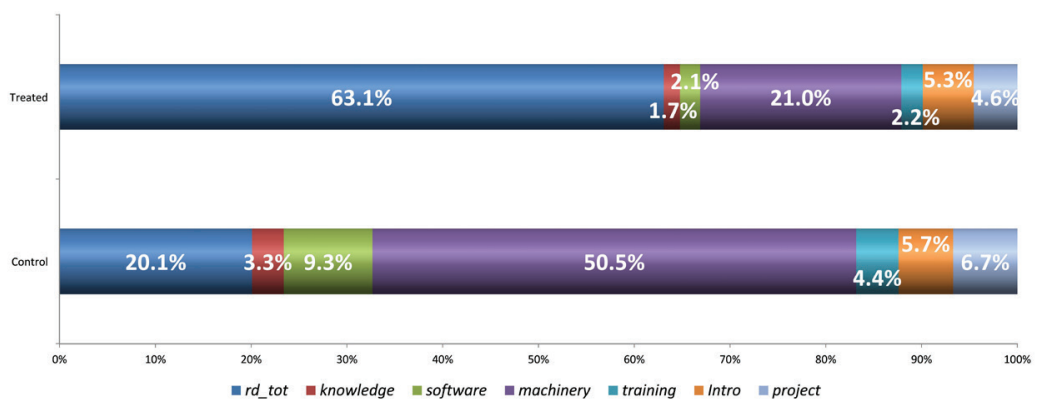

Source: IBGE (2011, confidential microdata).

FIGURE 2

Average share of researchers by educational level in 2011 for treatment and control groups

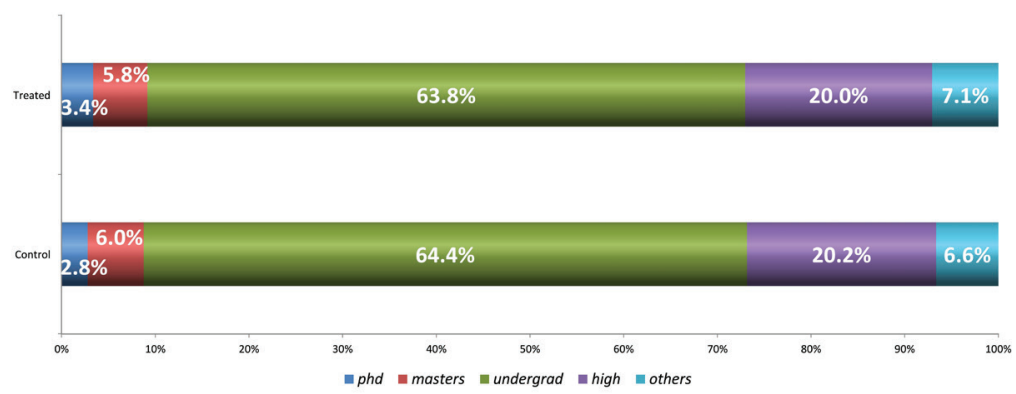

Source: IBGE (2011, confidential microdata).

\footnotetext{
7 The PINTEC survey and database follow closely the Oslo Manual (OECD, 2005) on the group of expenditures included in the category of innovative activities, as discussed in section 2 above.

8 Workers with partial dedication are weighted according to the share of their time dedicated to the firm's research activities.
} 
FIGURE 3

Share of innovative firms by type of innovation achieved in 2009-2011 for treatment and control groups

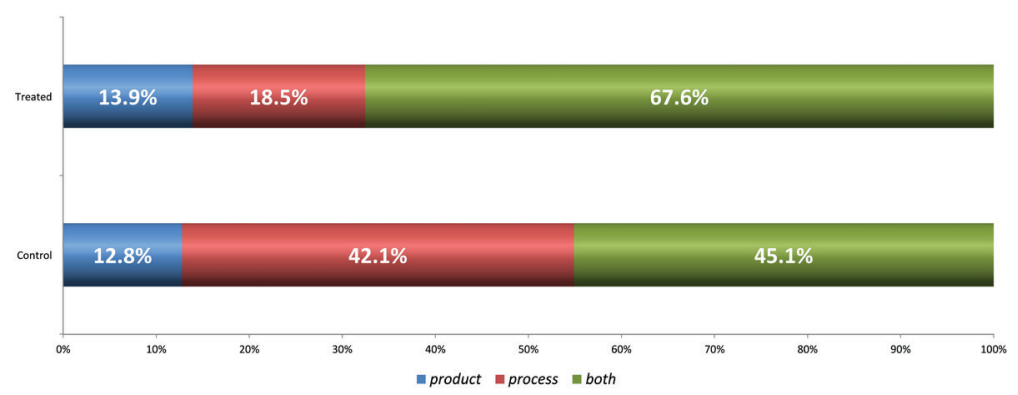

Source: IBGE (2011, confidential microdata).

In this analysis, covariates $\left(X_{i}\right)$ are the factors determining the probability of a firm obtaining the tax incentives, as estimated by the propensity score. They include the size, age, location, revenue, origin of controlling capital, continuous R\&D activity and other features of each firm. The list of all covariates, their definitions and descriptive statistics are presented in Tables A.2 to A.4 of the Supplementary Material. These variables are observed at the same period of treatment (2011 in the case of different innovative activities and educational level of research personnel, and 2008 for type of innovation).

\section{Results}

Table 3 presents the results of the estimated propensity score for each group of outcome variables under study. In most cases, coefficients of the covariates have the same sign, supporting the specification of the treatment probability model. Pseudo r-square ranges from 0.17 to 0.35 , and log-likelihood ranges from -468 to -332 .

Results of the means test ${ }^{9}$ indicate that for nearly all covariates there are no significant differences (at a 95\% confidence level) between matched treated and control groups. Most covariates present a substantial reduction of standardized bias in matched samples, and, in all cases, the log-likelihood test ( $p>c h i 2)$ does not reject joint insignificance hypothesis. Pseudo-R2, mean, and median bias also drop considerably for the matched groups. These results suggest that the covariates are sufficiently balanced, providing good grounds for accepting the propensity score specification.

9 See Tables A.5 to A.7 in the Supplementary Material. 
TABLE 3

Estimated propensity score for each broad classification

\begin{tabular}{|c|c|c|c|}
\hline \multirow{2}{*}{ Covariate } & \multicolumn{3}{|c|}{ Broad Classification } \\
\hline & Innovative activities & Educational level & Type of innovation \\
\hline personnel & $-0.076(0.15)$ & $0.004(0.148)$ & $0.43(0.193)^{* *}$ \\
\hline age & $-0.001(0.008)$ & $0.004(0.008)$ & $0.005(0.008)$ \\
\hline nac_control & $-0.643(0.513)$ & $-0.785(0.511)$ & $-0.605(0.492)$ \\
\hline for_control & $-0.562(0.497)$ & $-0.506(0.496)$ & $-0.117(0.492)$ \\
\hline rd_cont & $1.465(0.209)^{* * *}$ & $0.908(0.385)^{* *}$ & $1.46(0.256)^{* * *}$ \\
\hline group & $0.212(0.205)$ & $0.277(0.207)$ & $0.412(0.232)^{*}$ \\
\hline revenue & $0.714(0.137)^{* * *}$ & $0.509(0.133)^{* * *}$ & $0.344(0.162)^{* *}$ \\
\hline$i m p$ & $0.85(0.388)^{* *}$ & $0.808(0.425)^{*}$ & $1.168(0.624)^{*}$ \\
\hline $\exp$ & $0.432(0.268)$ & $0.271(0.29)$ & $0.553(0.409)$ \\
\hline for_market & $-0.888(0.422)^{* *}$ & $-0.73(0.371)^{* *}$ & $-0.4(0.376)$ \\
\hline dummyN & $-0.11(0.712)$ & $-1.216(0.765)$ & $-0.348(0.606)$ \\
\hline dummyNE & $-0.44(0.443)$ & $-0.501(0.458)$ & $-0.254(0.574)$ \\
\hline dummySE $E^{b}$ & $-0.025(0.272)$ & $0.127(0.268)$ & $-0.371(0.391)$ \\
\hline dummyS & $0.404(0.21)^{*}$ & $0.13(0.229)$ & $1.022(0.255)^{* * *}$ \\
\hline dummyCO & $-0.985(0.785)$ & $-0.6(0.707)$ & $\mathrm{n} / \mathrm{a}^{\mathrm{a}}$ \\
\hline constant $\left(\beta_{0}\right)$ & $-9.745(1.755)^{* * *}$ & $-6.116(2.013)^{* * *}$ & $-8.263(1.868)^{* * *}$ \\
\hline$N$ & 2,311 & 1,144 & 2,683 \\
\hline Log-likelihood & -468.367 & -406.315 & -336.785 \\
\hline PseudoR2 & 0.268 & 0.170 & 0.356 \\
\hline Prob $>$ chi2 & 0.000 & 0.000 & 0.000 \\
\hline
\end{tabular}

Logit model. Standard error in parenthesis. ${ }^{*} \mathrm{p}<.10 ;{ }^{* *} \mathrm{p}<.05 ;{ }^{* * *} \mathrm{p}<.01$. Sector dummies' coefficients suppressed for presentation purposes. ${ }^{a}$ Excluded due to perfect collinearity. ${ }^{b}$ Not considered firms in the state of São Paulo.

The ATT estimated for each outcome variable is displayed in Table 4, along with the respective standard errors and confidence level indicators. In the analysis of innovative activities, the results confirm our first proposition: the average impact of the policy on R\&D spending of beneficiary firms in 2011 was around 1.1 million Brazilian reais (or six hundred thousand dollars). ${ }^{10}$ This value represents $17 \%$ of the mean R\&D spending of beneficiary firms that year. ${ }^{11}$ None of the other categories had an impact close to this magnitude, indicating an increase of the R\&D intensity of the bundle of innovative activities. 
TABLE 4

Estimated average treatment effect on the treated (ATT)

\begin{tabular}{|c|c|c|c|c|c|}
\hline \multirow{2}{*}{$\begin{array}{c}\text { Broad } \\
\text { Classifica- } \\
\text { tion }\end{array}$} & \multirow[b]{2}{*}{ Unit } & \multirow[b]{2}{*}{ Variable } & \multicolumn{2}{|c|}{ Mean } & \multirow[b]{2}{*}{ ATT } \\
\hline & & & Treated & Control & \\
\hline \multirow{7}{*}{$\begin{array}{c}\text { Different } \\
\text { innovative } \\
\text { activities }\end{array}$} & \multirow{7}{*}{$\begin{array}{c}\text { Brazilian R\$ } \\
1,000\end{array}$} & $r d \_t o t$ & $1,036.61$ & -55.82 & $\begin{array}{c}1,092.43^{* * *} \\
(377.9)\end{array}$ \\
\hline & & knowledge & -73.06 & 127.90 & $\begin{array}{c}-200.96^{* *} \\
(95.31)\end{array}$ \\
\hline & & software & -47.62 & -98.68 & $\begin{array}{c}51.06 \\
(122.54)\end{array}$ \\
\hline & & machinery & -308.36 & 197.02 & $\begin{array}{l}-505.38 \\
(397.51)\end{array}$ \\
\hline & & training & 18.42 & -7.78 & $\begin{array}{c}26.21 \\
(78.87)\end{array}$ \\
\hline & & intro & -109.07 & 271.34 & $\begin{array}{c}-380.41^{* *} \\
(187.72)\end{array}$ \\
\hline & & project & -160.99 & -155.74 & $\begin{array}{c}-5.25 \\
(179.5)\end{array}$ \\
\hline \multirow{5}{*}{$\begin{array}{c}\text { Educational } \\
\text { Level }\end{array}$} & \multirow{5}{*}{$\begin{array}{l}\text { Number of } \\
\text { researchers }\end{array}$} & phd & 0.00 & 0.04 & $\begin{array}{l}-0.04 \\
(0.13)\end{array}$ \\
\hline & & master & 0.31 & 0.29 & $\begin{array}{c}0.01 \\
(0.24)\end{array}$ \\
\hline & & undergrad & & & $\begin{array}{l}3.35^{* *} \\
(1.61)\end{array}$ \\
\hline & & high & 3.44 & 2.39 & $\begin{array}{c}1.05 \\
(1.46)\end{array}$ \\
\hline & & other & 0.96 & -0.43 & $\begin{array}{c}1.39 \\
(1.08)\end{array}$ \\
\hline \multirow{3}{*}{$\begin{array}{l}\text { Type of inno- } \\
\text { vation }\end{array}$} & \multirow{3}{*}{ Binary } & product & 0.15 & 0.15 & $\begin{array}{c}0 \\
\text { (omitted) }\end{array}$ \\
\hline & & process & 0.15 & 0.18 & $\begin{array}{c}-.031 \\
(0.55)\end{array}$ \\
\hline & & both & 0.70 & 0.67 & $\begin{array}{c}0.31 \\
(0.69)\end{array}$ \\
\hline
\end{tabular}

Standard errors in parenthesis. ${ }^{*} \mathrm{p}<.10 ;{ }^{* *} \mathrm{p}<.05 ;{ }^{* * *} \mathrm{p}<.01$. Matching algorithm: nearest neighbor. ATT for different innovative activities and educational level variables calculated through linear regression with standard error estimated according to Abadie and Imbens (2006). ATT for type of innovation variables calculated through logistic regression - conditional marginal effects reported.

Part of such increase was counterbalanced by a reduction of investments in other innovative activities. Firms benefiting from tax incentives experienced an average reduction of expenditures on (a) acquisition of external knowledge (of around 200,000 Brazilian reais or 110,000 U.S. dollars), and (b) introduction of innovations in the market (of around 380,000 Brazilian reais or 200,000 U.S. dollars). ${ }^{12}$ The

12 Values converted to U.S. dollars according to the exchange rate applicable on the last day of 2011. 
estimation does not yield evidence of impact on other innovative activities, as the statistical significance does not achieve a minimum confidence level.

In terms of the composition of the research staff, firms incentivized by the policy increased the number of researchers with undergraduate degrees only. On average, these enterprises hired 3.35 more researchers with such a background because of the policy. The effect is significant at a $95 \%$ confidence level, and it represents $21.4 \%$ of the average number of researchers with this educational level hired by beneficiary firms in 2011, and $12.8 \%$ of their average R\&D staff. ${ }^{13}$ On the other hand, no significant impact on research personnel with graduate degree was found. These results support our second proposition that the policy positively affected the educational level of the R\&D team, but had no effect on highly-qualified researchers, confirming our second proposition.

The empirical study does not present evidence of policy impact on the type of innovation pursued by beneficiary firms, as suggested by our third proposition. Although Figure 3 shows that beneficiary firms did less 'process innovation only', the difference between treated and control groups does not stand after the matching. In this sense, it is not possible to maintain that the policy had any effect on the decision of firms for this classification.

In general, results for robustness checks ${ }^{14}$ (coefficient signs and statistical significance) follow closely those of the main model, suggesting that they are not sensitive to the estimator applied. The Rosenbaum bounds analysis ${ }^{15}$ of sensitiveness to hidden bias indicates that coefficients lose significance between 1.2 and 1.3 for the $R \& D$ and external knowledge acquisition variables. This means that a hidden variable not considered in the propensity score model should affect the odds of treatment ratio by a minimum of $20 \%$ to render the estimation results spurious. Considering the large group of covariates used to estimate the propensity score and that the difference-in-difference estimators excluded any chance of endogeneity arising from fixed effects, the results may be considered moderately insensitive to hidden bias. The impact on expenditures with the introduction of innovations in the market and hiring of researchers with undergraduate degrees, on the other hand, is less robust, as statistical significance is not found for values of $(\Gamma)$ above 1.2 .

13 Mean number of undergraduate researchers hired by beneficiary firms in the sample in 2011 is 15.66 ; average size of their R\&D staff is 26.9 .

14 See Table A.8 in the Supplementary Material.

15 See Table A.9 in the Supplementary Material. 


\subsection{Discussion of the results}

The results presented herein are analyzed in light of the theoretical and empirical literature, and of the policy design discussed in the previous sections. The first point to stress refers to the notion of behavioral additionality of the policy. A positive impact was found for only one of the categories of innovative activities and groups of R\&D personnel, with negative or no significant effect on the others. The uneven results for distinct variables within the same broad classification implies that the overall composition of firms' innovation bundle has changed, which may be construed as a modification of their strategies, according to the behavioral additionality literature discussed in section 2 . The study, in this sense, provides new evidence and elements to comprehend the effects and downsides of the Brazilian tax incentives that have not been considered in previous studies, confirming the importance of the behavioral additionality approach to better understand the impact and dynamics of innovation policies.

Our estimates for expenditures on innovative activities indicate that beneficiary firms changed how they obtain and apply new knowledge. According to our results, the policy led companies to adopt a higher 'tech orientation' (PINGFANG et al., 2006) by increasing the R\&D intensity of their spending. This finding disputes the argument by David et al. (2000) that beneficiary firms are more likely to seek short-run profit. Our findings contrast with the conclusions of Pingfang et al. (2006) for tax incentives, but it is in accordance with the results of Clausen (2009) for direct subsidies.

The increase in the number of researchers with undergraduate degrees confirms our second proposition. Although the result may constitute a positive input additionality, it is problematic from a behavioral additionality perspective. The absence of impact on researchers with graduate degrees indicates that the policy had limited impact on firms' innovative skills and knowledge, with reduced effects on their or ability to develop more technologically advanced projects. Comparing these results with previous studies, Clausen (2009) and Dumont et al. (2015) found evidence of impact on the number of qualified researchers with $\mathrm{PhD}$ or master's degrees, while Afcha and García-Quevedo (2016) did not reach any significant results.

Finally, the absence of impact on the 'type of innovation' outcome variables is a sign that the tax incentives did not influence the choice of firms to pursue product or process innovation. The result differs from Aralica and Botrić (2013), who found product-process innovation balance to be affected by the Croatian government 
policy, and from Hyvärinen (2006), who reported that Finish incentivized firms were more likely to engage in product innovation.

A group of policy implications can be drawn from this empirical study. First, the increase of R\&D intensity in the bundle of innovative investments can be considered a positive result, as strict $R \& D$ is generally related to innovation projects with higher technological levels (PINGFANG et al., 2006) and knowledge spillovers. The absence of impact on the number of researchers with graduate training is an important negative result that needs to be addressed. Establishing a system of incentives and cost reductions that stimulates demand for a more qualified research workforce seems particularly relevant to improve the policy design. The Belgian case described and tested by Neicu et al. (2016) and Dumont et al. (2015) presents a viable option and first basis for such improvement. At last, the design of incentives particularly suited to impact process innovation constitutes another challenge to be addressed. OECD (2015b) stressed that the weakness of Brazilian productivity rates is one of the main reasons explaining low GDP per capita levels compared to developed economies.

One last comment refers to the external validity of the results. The PINTEC sample is not random, and the presence of a firm in each edition of the survey is affected by its level of innovative activities, among other factors such as economic sector, location and size (IBGE, 2010, 2013). As our estimation strategy considers two editions of PINTEC, and as the mentioned features are likely to be correlated with the treatment and outcome variables, attrition issues may jeopardize external validity (MILLER; HOLLIST, 2007). For this reason, our findings should be considered with caution when generalized to the entire group of beneficiary firms of Law 11,196/05 (BRASIL, 2005), although they provide a first estimate of impact on the variables considered herein.

\section{Conclusion}

This paper presents an empirical study on the impact of innovation tax incentives established in Brazil by Law 11,196/05 (BRASIL, 2005) on the composition of private innovation investment and their results. The behavioral additionality analysis used herein is a recent dimension of the evaluation of innovation policies in the international economic literature, and it is virtually unexplored in Brazil.

The three main conclusions of the study are: (a) there is a positive effect on total $R \& D$ expenditures, raising the $R \& D$ intensity within the bulk of innovative 
activities; (b) the policy fostered additional hiring of researchers with an undergraduate degree, without a significant impact on personnel with higher educational levels; and (c) there is no evidence that the policy affected the balance between product and process innovation.

Besides presenting relevant information for improving the design and structure of the policy, this paper provides empirical support to maintain that the fiscal benefits of Law 11,196/05 (BRASIL, 2005) have contributed to the development of private innovation in Brazil. It also evidences that tax incentives can contribute to a broader innovation policy in an evolutionary and structuralist perspective (GÖK; EDLER, 2012; NEICU et al., 2016). The change in the composition of investments and results indicates that firms' behavior and strategies were affected by the policy, a result that is not limited to raising R\&D levels to compensate for market failures (HALL; MAIRESSE; MOHNEN, 2010). This opens the possibility for such incentives to be designed to direct private innovation investments to achieve broader societal goals, such as either technological catch-up and raising environmental standards.

\section{References}

AFCHA, S.; GARCÍA-QUEVEDO, J. The impact of R\&D subsidies on R\&D employment composition. Industrial and Corporate Change, v. 25, n. 6, p. 955-975, 2016.

AGGARWAL, V. A.; HSU, D. H.; WU, A. R\&D production team organization and firmlevel innovation. 2015 (working paper).

ARALICA, Z.; BOTRIĆ, V. Evaluation of research and development tax incentives scheme in Croatia. Ekonomska Istrazivanja-Economic Research, v. 26, n. 3, p. 63-80, 2013.

ARAÚJO, B. C. Incentivos fiscais à pesquisa e desenvolvimento e custos de inovação no Brasil. Radar, n. 9, p. 3-11, ago. 2010.

BACH, L.; MATT, M. Rationale for science \& technology policy. In: GEORGHIOU, L.; RIGBY, J.; CAMERON, H. (Ed.). Assessing the Socio-Economic Impacts of the Framework Programme (ASIF)'. Report to European Commission DG Research. European Commission DG Research, 2001. p. 93-145.

BARGE-GIL, A.; LÓPEZ, A. R versus D: Estimating the differentiated effect of research and development on innovation results. Industrial and Corporate Change, v. 24, n. 1, p. 93-129, 2014. 
BELADI, H.; MARJIT, S.; YANG, L. Outsourcing: volume and composition of R\&D. Review of International Economics, v. 20, n. 4, p. 828-840, 2012.

BLOOM, N.; CHENNELLS, L.; GRIFFITH, R.; VAN REENEN, J. How has tax affected the changing cost of R\&D? Evidence from eight countries. In: SMITH, H. L. (Ed.). The regulation of science and technology. New York: Palgrave, 2002. p. 136-160.

BRASIL. Diretrizes de política industrial, tecnológica e de comércio exterior. Available at <http://www.abdi.com.br/Estudo/Diretrizes_PITCE.pdf>. Brasilia, 2003.

Lei no 11.196, de 21 de novembro de 2005. Available at <http://www.planalto. gov.br/ccivil_03/_ato2004-2006/2005/lei/111196.htm>.

BRASIL. Ministério da Ciência, Tecnologia, Inovaçôes e Comunicações. Lei do Bem Utilização dos incentivos fiscais à inovação tecnológica - ano base 2014. Brasília, 2016a. Available at <http:/www.mctic.gov.br/mctic/export/sites/institucional/arquivos/veja_tambemlei_bem/Relatorio-Anual-Lei-11.196-05-Ano-Base-2014-Retificado.pdf>.

Recursos aplicados, governo federal. Brasília, 2016b. Available at <http://www. mctic.gov.br/mctic/opencms/indicadores/detalhe/recursos_aplicados/governo_federal/2_2_3. html>.

BRASIL. Ministério da Indústria, Comércio Exterior e Serviços. Empresas brasileiras importadoras e exportadoras. Brasília, s.d. Available at <http://mdic.gov.br/comercio-exterior/ estatisticas-de-comercio-exterior/empresas-brasileiras-exportadoras-e-importadoras >

BUISSERET, T. J.; CAMERON, H. M.; GEORGHIOU, L. What difference does it make? Additionality in the public support of $R \& D$ in large firms. International Journal of Technology Management, v. 10, n. 4-6, p. 587-600, 1995.

BUSOM, I.; FERNÁNDEZ-RIBAS, A. The impact of firm participation in R\&D programmes on R\&D partnerships. Research Policy, v. 37, n. 2, p. 240-257, 2008.

CLARYSSE, B.; BILSEN, V.; STEURS, G. Behavioural additionality of the R\&D subsidies programme of IWT-Flanders (Belgium). Government R\&D Funding and Company Behaviour: Measuring Behavioural Additionality. Paris: OECD, 2006. p. 91-114.

CLARYSSE, B.; WRIGHT, M.; MUSTAR, P. Behavioural additionality of R\&D subsidies: a learning perspective. Research Policy, v. 38, n. 10, p. 1517-1533, 2009.

CLAUSEN, T. H. Do subsidies have positive impacts on R\&D and innovation activities at the firm level? Structural Change and Economic Dynamics, v. 20, n. 4, p. 239-253, 2009. 
COHEN, W. M.; KLEPPER, S. Firm size and the nature of innovation within industries: the case of process and product R\&D. The review of Economics and Statistics, v. 78, n. 2, 1996, p. 232-243.

CUNNINGHAM, P.; GÖK, A.; LARÉDO, P. The impact of direct support to R\&D and innovation in firms. Manchester Institute of Innovation Research, 2012.

DAVID, P. A.; HALL, B. H.; TOOLE, A. A. Is public R\&D a complement or substitute for private R\&D? A review of the econometric evidence. Research Policy, v. 29, n. 4, p. 497-529, 2000.

DEHEJIA, R. H.; WAHBA, S. Causal effects in, nonexperimental studies: Reevaluating the evaluation of training programs. Journal of the American Statistical Association, v. 94, n. 448, p. 1053-1062, 1999.

. Propensity score-matching methods for nonexperimental causal studies. Review of Economics and Statistics, v. 84, n. 1, p. 151-161, 2002.

DIPRETE, T. A.; GANGL, M. Assessing bias in the estimation of causal effects: Rosenbaum bounds on matching estimators and instrumental variables estimation with imperfect instruments. Sociological Methodology, n, 34, p. 271-310, 2004.

DUMONT, M.; SPITHOVEN, A.; TEIRLINCK, P. Public support for R\&D and the educational mix of R\&D employees. CESifo Economic Studies, v. 62, n. 3, p. 426-452, 2015.

EBERSBERGER, B. Public funding for innovation and the exit of firms. Journal of Evolutionary Economics, v. 21, n. 3, p. 519-543, 2011.

EUROPEAN COMMISSION. Horizon 2020 indicators: assessing the results and impact of Horizon. Luxembourg, 2015.

FALK, R. Measuring the effects of public support schemes on firms' innovation activities: Survey evidence from Austria. Research Policy, v. 36, n. 5, p. 665-679, 2007.

FELDMAN, M. P.; KELLEY, M. R. Leveraging research and development: assessing the impact of the US Advanced Technology Program. Small Business Economics, v. 20, n. 2, p. $153-165,2003$.

GEORGHIOU, L. Impact of the framework programme on European industry. European Commission, Directorate General Telecommunications, Information Market and Exploitation of Research, 1994.

. Impact and additionality of innovation policy. Innovation Science and Technology

IWT Observatory, n. 40, p. 57-65, 2002. 
GEORGHIOU, L.; CLARYSSE, B. Introduction and synthesis. In OECD. Government R\&D funding and company behaviour - Measuring behavioural additionality. Paris: OECD Publishing, 2006.

GÖK, A.; EDLER, J. (The use of behavioural additionality evaluation in innovation policy making. Research Evaluation, v. 21, n. 4, p. 306-318, 2012.

HALL, B. H.; MAIRESSE, J.; MOHNEN, P. Measuring the returns to R\&D. Handbook of the economics of innovation. Elsevier, 2010. v. 2, p. 1033-1082.

HALL, B. H.; VAN REENEN, J. How effective are fiscal incentives for R\&D? A review of the evidence. Research Policy, v. 29, n. 4-5, p. 449-469, 2000.

HSU, F.-M.; HORNG, D.-J.; HSUEH, C.-C. The effect of government-sponsored R\&D programmes on additionality in recipient firms in Taiwan. Technovation, v. 29, n. 3, p. 204-217, 2009.

HYVÄRINEN, J. Behavioural additionality of public R\&D funding in Finland. Government $\mathrm{R} \& D$ funding and company behaviour: measuring behavioural additionality. Paris: OECD, 2006. p. $115-125$.

IBGE. Pesquisa de Inovação Tecnológica 2008. Rio de Janeiro, 2010. . Pesquisa de Inovação Tecnológica 2011. Rio de Janeiro, 2013.

IFS, I. A study on R\&D tax incentives. Final report. European Commission, 2015. Available at <https://ec.europa.eu/futurium/en/system/files/ged/28-taxud-study_on_rnd_ tax_incentives_-_2014.pdf>.

JAFFE, A. B.; LE, T. The impact of R\&D subsidy on innovation: a study of New Zealand firms. Cambridge, MA: National Bureau of Economic Research, 2015 (NBER Working Paper Series, 21479).

KANNEBlEY JR., S.; ARAÚJO, B. C.; MAFFIOLI, A.; STUCCHI, R. Productive development policies and innovation spillovers through labor force mobility: the case of the Brazilian innovation support system. Inter-American Development Bank, 2013 (IDB working paper series, 459).

KANNEBLEY JR., S.; SILVEIRA PORTO, G. Incentivos fiscais à pesquisa, desenvolvimento e inovação no Brasil: uma avaliação das políticas recentes. Inter-American Development Bank, 2012 (Documento para discussão, 236).

KÖHLER, C.; LAREDO, P.; RAMMER, C. The impact and effectiveness of fiscal incentives for R\&D. Compendium of Evidence on the effectiveness of Innovation Policy. University of Manchester, 2012 (Nesta Working Paper, 12/01) 
LADINSKA, E.; NON, M.; STRAATHOF, B. More R\&D with tax incentives? A metaanalysis. CPB Netherlands Bureau for Economic Policy Analysis, 2015 (Discussion Paper, 309). LIN, P.; SAGGI, K. Product differentiation, process R\&D, and the nature of market competition. European Economic Review, v. 46, n. 1, p. 201-211, 2002.

LÓPEZ, A. Innovation and appropriability, empirical evidence and research agenda. The economics of intellectual property: suggestions for further research in developing countries and c.ountries with economies in transition. Geneva: World Intellectual Property Organization (WIPO), 2009.

MILlER, R.; HOLLIST, C. Attrition bias. In: SALKIND, N. J. (Ed.). Encyclopedia of Measurement and Statistics. Thousand Oaks: Sage Reference, 2007. v. 1, p. 57-60.

NEICU, D.; TEIRLINCK, P.; KELCHTERMANS, S. Dipping in the policy mix: Do R\&D subsidies foster behavioral additionality effects of R\&D tax credits? Economics of Innovation and New Technology, v. 25, n. 3, p. 218-239, 2016.

OECD. Oslo Manual: Guidelines for collecting and interpreting innovation data. 3. ed. Paris: OECD Publishing, 2005.

. Government R \& D funding and company behaviour: measuring behavioural additionality. Paris: OECD Publishing, 2006.

. Supporting investment in knowledge capital, growth and innovation. Paris: OECD Publishing, 2013

. Frascati Manual 2015: guidelines for collecting and reporting data on research and experimental development. Paris: OECD Publishing, 2015a.

. OECD economic surveys: Brazil. Paris: OECD Publishing, 2015b. Available at <http://www.oecd.org/eco/surveys/Brazil-2015-overview.pdf>.

. OECD science, technology and industry scoreboard 2015. Paris: OECD Publishing, 2015c.

OECD science, technology and innovation outlook 2016. Paris: OECD Publishing, 2016.

PINGFANG, Z.; WEIMIN, X.; LUNDIN, N. The impact of government's fundings and tax incentives on industrial R\&D investments - Empirical evidences from industrial sectors in Shanghai. China Economic Review, v. 17, n. 1, p. 51-69, 2006.

ROSENBAUM, P. R. Design of observational studies. New York: Springer, 2012.

SAHA, S. R\&D composition over the product life cycle. Minneapolis, MN: Center for Economic Research, University of Minnesota, 1999 (Discussion Paper, n. 309). 
SHIMADA, E. Efetividade da lei do bem no estímulo ao investimento em P\&D: uma análise com dados em painel. São Paulo: Universidade de São Paulo, 2014.

SPITHOVEN, A.; TEIRLINCK, P. External R\&D: exploring the functions and qualifications of R\&D personnel. International Journal of Innovation Management, v. 14, n. 6, p. $967-$ $987,2010$.

SUZUKI, J.; YUMITORI, S. Behavioural additionality of public R\&D funding in Japan. In: OECD. Government R\&D funding and company behaviour: measuring behavioural additionality. Paris: OECD, 2006.

WARDA, J. B-index time series 1981-2011. 2013. (Discussion paper). Available at $<$ http:// www.oecd-ilibrary.org/science-and-technology/oecd-science-technology-and-industryoutlook-2014/tax-incentives-for-r-amp-d-and-innovation_sti_outlook-2014-18-en>.

ZÚNIIGA-VICENTE, J. Á.; ALONSO-BORREGO, C.; FORCADELL, F. J.; GALÁN, J. I. Assessing the effect of public subsidies on firm R\&D investment: a survey. Journal of Economic Surveys, v. 28, n. 1, p. 36-67.

\section{Acknowledgments}

The authors acknowledge the financial support of the CAPES (Coordination for the Improvement of Higher Education Personnel) and FIPE (Institute of Economic Research). Access to PINTEC confidential microdata granted by permission of IBGE (03605.000637/2015-70). 


\section{Supplementary material}

TABLE A.1

List and definition of outcome variables

\begin{tabular}{|c|c|c|c|}
\hline $\begin{array}{c}\text { Broad } \\
\text { classification }\end{array}$ & Unit & $\begin{array}{l}\text { Outcome } \\
\text { variable }\end{array}$ & Definition \\
\hline \multirow{7}{*}{ Innovative activities } & \multirow{7}{*}{$\begin{array}{l}\text { Brazilian } \\
\mathrm{R} \$ 1,000\end{array}$} & $r d$ tot & Total R\&D \\
\hline & & knowledge & Acquisition of knowledge from third parties \\
\hline & & software & Software license or acquisition \\
\hline & & machinery & Acquisition of machinery and equipment \\
\hline & & training & Training \\
\hline & & intro & Introduction of innovations in the market \\
\hline & & project & Industrial design and other measures \\
\hline \multirow{5}{*}{$\begin{array}{l}\text { Educational level of } \\
\text { R\&D personnel }\end{array}$} & \multirow{5}{*}{$\begin{array}{l}\text { Number of } \\
\text { researchers }\end{array}$} & phd & PhD degree \\
\hline & & master & Master's degree \\
\hline & & undergrad & Undergraduate level ${ }^{(1)}$ \\
\hline & & high & High school level \\
\hline & & others & Others \\
\hline \multirow{3}{*}{ Type of innovation } & \multirow{3}{*}{ Binary } & product & Product innovation only \\
\hline & & process & Process innovation only \\
\hline & & both & Both product and process innovation \\
\hline
\end{tabular}

Source: IBGE (2013, confidential microdata).

(1) First level or bachelor's degree. In Brazil, such a degree is commonly referred to as either "graduação" or "bacharelado".

TABLE A.2

List and definition of covariates used in the propensity score models

\begin{tabular}{ll}
\hline \multicolumn{1}{c}{ Covariate } & \\
\hline $\begin{array}{l}\text { personnel } \\
\text { age }\end{array}$ & Firm size (number of employees_log-linearized) \\
nac_control & Firm age \\
for_control & Dummy for national controlling capital \\
rd_cont & Dummy for foreign controlling capital \\
group & Dummy for continuous R\&D activity in the last three years \\
revenue & Dummy for firms belonging to a corporate group \\
imp & Net revenue (log-linearized) \\
exp & Dummy for importing firms in (t-1) \\
for_market & Dummy for exporting firms in (t-1) \\
dummyN & Dummy for main firm market being international \\
dummyNE & Dummies for the North region \\
dummyCO & Dummies for the Northeast region \\
dummySE & Dummies for the Midwest region \\
dummyS & Dummies for the Southeast region (excluding firms from the state of São Paulo to \\
cnae_(dummies) & avoid perfect collinearity) \\
\hline
\end{tabular}

Source: IBGE (2013, confidential microdata); BRASIL (s.d.). 


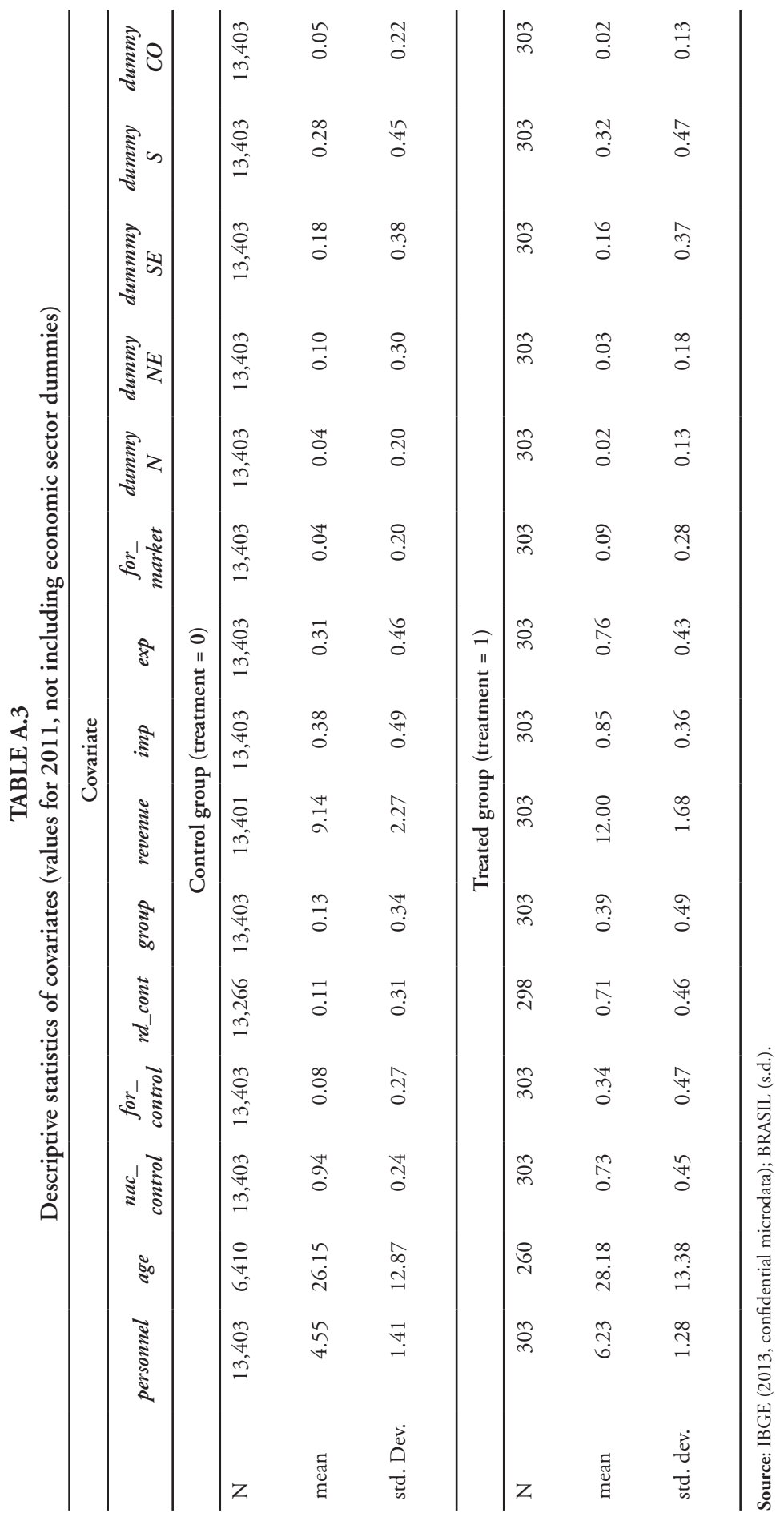




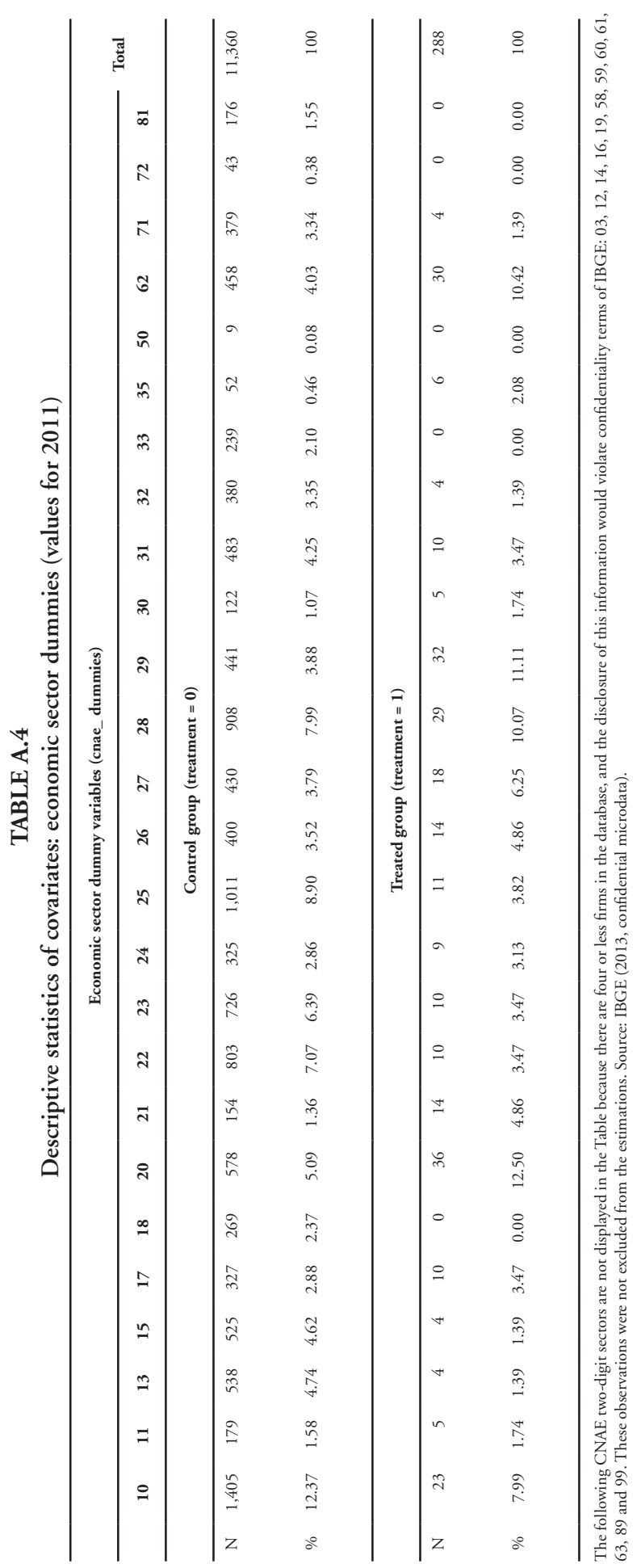


TABLE A.5

Results of the means test for the estimated propensity score.

Broad classification: different innovative activities

\begin{tabular}{|c|c|c|c|c|c|c|c|}
\hline \multirow{2}{*}{ Covariate } & \multicolumn{2}{|c|}{ Mean } & \multirow{2}{*}{ \%bias } & \multirow{2}{*}{$\begin{array}{c}\% \text { reduct } \\
\text { |bias| }\end{array}$} & \multicolumn{2}{|c|}{ t-test } & \multirow{2}{*}{$\begin{array}{l}\mathrm{V}(\mathrm{T}) / \\
\mathrm{V}(\mathrm{C})^{\mathrm{b}}\end{array}$} \\
\hline & Treated & Control & & & $t$ & $\mathbf{p}>|\mathbf{t}|$ & \\
\hline revenue & $3.00 \mathrm{E}+05$ & $4.30 \mathrm{E}+05$ & -9.6 & 71.8 & -1.42 & 0.158 & 0.31 \\
\hline personnel & 6.1522 & 6.1492 & 0.3 & 99.7 & 0.03 & 0.978 & 0.86 \\
\hline age & 28 & 29.815 & -13.8 & 15.5 & -1.29 & 0.199 & 1.03 \\
\hline nac_control & 0.73034 & 0.70787 & 5.9 & 87.7 & 0.47 & 0.638 & . \\
\hline for_control & 0.30337 & 0.33708 & -8.4 & 82 & -0.68 & 0.497 & . \\
\hline rd_cont & 0.78652 & 0.7809 & 1.3 & 98.7 & 0.13 & 0.898 & . \\
\hline group & 0.3427 & 0.32022 & 5.2 & 86.9 & 0.45 & 0.654 & . \\
\hline imp & 0.86517 & 0.8764 & -2.7 & 95.4 & -0.32 & 0.753 & . \\
\hline $\exp$ & 0.77528 & 0.80337 & -6.1 & 89.7 & -0.65 & 0.517 & . \\
\hline for_market & 0.05056 & 0.07303 & -10.2 & -410.4 & -0.88 & 0.38 & . \\
\hline dummyN & 0.01685 & 0.00562 & 7.9 & -28.2 & 1 & 0.316 & . \\
\hline dummyNE & 0.03933 & 0.04494 & -2.3 & 88.5 & -0.26 & 0.793 & . \\
\hline dummySE & 0.14607 & 0.17416 & -7.8 & -78 & -0.72 & 0.471 & . \\
\hline dummySa & 0.33146 & 0.29213 & 8.4 & -18 & 0.8 & 0.425 & . \\
\hline dummyCO & 0.01124 & 0 & 7.5 & 54.8 & 1.42 & 0.157 & . \\
\hline cnae_10 & 0.10112 & 0.08989 & 3.6 & -22 & 0.36 & 0.719 & . \\
\hline cnae_11 & 0.01124 & 0.02247 & -10.8 & -2666.7 & -0.82 & 0.412 & . \\
\hline cnae_12 & 0 & 0 & 0 & 100 & . & . & . \\
\hline cnae_13 & 0.01685 & 0.01124 & 3.2 & 82.2 & 0.45 & 0.654 & . \\
\hline cnae_14 & 0.00562 & 0 & 3.9 & 82.7 & 1 & 0.318 & . \\
\hline cnae_15 & 0.01124 & 0 & 8 & 40.4 & 1.42 & 0.157 & . \\
\hline cnae_16 & 0 & 0 & 0 & 100 & . & . & . \\
\hline cnae_17 & 0.04494 & 0.05056 & -2.8 & 64.4 & -0.25 & 0.804 & . \\
\hline cnae_18 & 0 & 0 & 0 & 100 & . & . & . \\
\hline cnae_19 & 0 & 0 & 0 & 100 & . & . & . \\
\hline cnae_20 & 0.1236 & 0.1236 & 0 & 100 & 0 & 1 & . \\
\hline cnae_21 & 0.04494 & 0.0618 & -10.1 & 39.8 & -0.71 & 0.481 & . \\
\hline cnae_22 & 0.02247 & 0.00562 & 8 & 67.8 & 1.35 & 0.178 & . \\
\hline cnae_23 & 0.03371 & 0.05056 & -9.6 & -3281.6 & -0.79 & 0.43 & . \\
\hline cnae_24 & 0.01124 & 0.02809 & -13.2 & -45.7 & -1.14 & 0.253 & . \\
\hline cnae_25 & 0.04494 & 0.0618 & -7.3 & -5.4 & -0.71 & 0.481 & . \\
\hline cnae_26 & 0.03371 & 0.03933 & -2.8 & 71.4 & -0.28 & 0.778 & . \\
\hline cnae_27 & 0.08427 & 0.07865 & 2.3 & 84.9 & 0.19 & 0.847 & . \\
\hline cnae_28 & 0.08989 & 0.06742 & 7.9 & -447.1 & 0.79 & 0.432 & . \\
\hline cnae_29 & 0.10674 & 0.1236 & -6.5 & 72 & -0.5 & 0.62 & . \\
\hline cnae_30 & 0.02247 & 0.01124 & 9.2 & 13 & 0.82 & 0.412 & . \\
\hline cnae_31 & 0.03933 & 0.03933 & 0 & 100 & 0 & 1 & . \\
\hline cnae_32 & 0.02247 & 0.01124 & 7.5 & -279.8 & 0.82 & 0.412 & . \\
\hline cnae_33 & 0 & 0 & 0 & 100 & - & - & - \\
\hline cnae_35 & 0 & 0 & 0 & 100 & . & . & . \\
\hline cnae_38 & 0 & 0 & . & . & . & . & . \\
\hline cnae_50 & 0 & 0 & 0 & 100 & . & . & . \\
\hline cnae_58 & 0 & 0 & 0 & 100 & . & . & . \\
\hline cnae_59 & 0 & 0 & . & . & . & . & . \\
\hline cnae_60 & 0 & 0 & 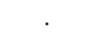 & . & . & . & . \\
\hline cnae_61 & 0.01124 & 0.00562 & 6.2 & -8.6 & 0.58 & 0.563 & . \\
\hline cnae_62 & 0.10112 & 0.11236 & -4.1 & 66.6 & -0.34 & 0.732 & . \\
\hline cnae_63 & 0.00562 & 0.00562 & 0 & 100 & 0 & 1 & . \\
\hline cnae_71 & 0 & 0 & 0 & 100 & . & . & . \\
\hline cnae_72 & 0 & 0 & 0 & 100 & . & . & . \\
\hline cnae_81 & 0 & 0 & 0 & 100 & . & . & . \\
\hline cnae_89 & 0.00562 & 0 & 8.3 & -271.1 & 1 & 0.318 & . \\
\hline cnae_91 & 0.00562 & 0 & 9.4 & -53.5 & 1 & 0.318 & . \\
\hline cnae_99 & 0 & 0 & & & & & \\
\hline Sample & Ps R2 & LR chi2 & $\mathrm{p}>\mathrm{chi} 2$ & MeanBias & MedBias & & \\
\hline Unmatched & 0.247 & 315.49 & 0 & 17.9 & 11.5 & & \\
\hline Matched & 0.038 & 18.59 & 0.979 & 4.8 & 4.7 & & \\
\hline
\end{tabular}

Variables' results for matched sample only.

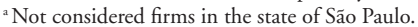

${ }^{\mathrm{b}}$ Variance ratio (for continuous covariates) of treated over non-treated. 
TABLE A.6

Results of the means test for the estimated propensity score.

Broad classification: educational level of R\&D staff

\begin{tabular}{|c|c|c|c|c|c|c|c|}
\hline \multirow{2}{*}{ Covariate } & \multicolumn{2}{|c|}{ Mean } & \multirow{2}{*}{ \%bias } & \multirow{2}{*}{$\begin{array}{c}\% \text { reduct } \\
\text { bias| }\end{array}$} & \multicolumn{2}{|c|}{ t-test } & \multirow{2}{*}{$\begin{array}{l}\mathrm{V}(\mathrm{T}) / \\
\mathrm{V}(\mathrm{C})^{\mathrm{b}}\end{array}$} \\
\hline & Treated & Control & & & $t$ & $\mathbf{p}>|\mathbf{t}|$ & \\
\hline revenue & $6.50 \mathrm{E}+05$ & $1.20 \mathrm{E}+06$ & -38 & -36.2 & -2.01 & 0.045 & 0.30 \\
\hline personnel & 6.4075 & 6.4722 & -5.4 & 92.7 & -0.48 & 0.635 & 0.55 \\
\hline age & 28.638 & 29.431 & -6 & 65.1 & -0.53 & 0.594 & 0.9 \\
\hline nac_control & 0.6954 & 0.74138 & -11.4 & 74.4 & -0.95 & 0.342 & . \\
\hline for_control & 0.34483 & 0.3046 & 9.3 & 77.1 & 0.8 & 0.424 & . \\
\hline rd_cont & 0.94828 & 0.97701 & -9.8 & 68.1 & -1.41 & 0.158 & . \\
\hline group & 0.41379 & 0.4023 & 2.5 & 93.7 & 0.22 & 0.828 & . \\
\hline imp & 0.89655 & 0.91379 & -4.5 & 90.3 & -0.55 & 0.584 & . \\
\hline $\exp$ & 0.8046 & 0.84483 & -9 & 78.3 & -0.99 & 0.325 & . \\
\hline for_market & 0.07471 & 0.06322 & 4.5 & -39.3 & 0.42 & 0.673 & . \\
\hline dummyN & 0.01724 & 0.01724 & 0 & 100 & 0 & 1 & . \\
\hline dummyNE & 0.04023 & 0.02874 & 5 & 67.6 & 0.59 & 0.558 & . \\
\hline dummySE & 0.17241 & 0.12644 & 12.5 & -220.6 & 1.2 & 0.23 & . \\
\hline dummySa & 0.26437 & 0.32184 & -12.7 & -51.4 & -1.18 & 0.24 & . \\
\hline dummyCO & 0.01724 & 0.01724 & 0 & 100 & 0 & 1 & . \\
\hline cnae_10 & 0.10345 & 0.10345 & 0 & 100 & 0 & 1 & . \\
\hline cnae_11 & 0.01724 & 0 & 14.2 & -322.6 & 1.74 & 0.082 & . \\
\hline cnae_12 & 0 & 0 & 0 & 100 & & . & . \\
\hline cnae_13 & 0.01724 & 0.01724 & 0 & 100 & 0 & 1 & . \\
\hline cnae_14 & 0.00575 & 0 & 5.9 & 28.8 & 1 & 0.318 & . \\
\hline cnae_15 & 0.01724 & 0.03448 & -11.5 & -39.7 & -1.01 & 0.312 & . \\
\hline cnae_16 & 0 & 0 & 0 & 100 & & . & . \\
\hline cnae_17 & 0.03448 & 0.08046 & -25.2 & -353.9 & -1.85 & 0.066 & . \\
\hline cnae_18 & 0 & 0 & 0 & 100 & . & . & . \\
\hline cnae_19 & 0 & 0 & 0 & 100 & & . & . \\
\hline cnae_20 & 0.13218 & 0.10345 & 9.1 & 18.4 & 0.83 & 0.407 & . \\
\hline cnae_21 & 0.06897 & 0.04023 & 13.4 & 24.8 & 1.18 & 0.239 & . \\
\hline cnae_22 & 0.01724 & 0.02299 & -3 & 86.5 & -0.38 & 0.704 & . \\
\hline cnae_23 & 0.02874 & 0.04598 & -10.2 & -488 & -0.85 & 0.398 & . \\
\hline cnae_24 & 0.02874 & 0.02299 & 3.7 & 7.2 & 0.34 & 0.736 & . \\
\hline cnae_25 & 0.04598 & 0.04023 & 2.6 & -297.6 & 0.26 & 0.793 & . \\
\hline cnae_26 & 0.04598 & 0.05172 & -2.3 & 85.6 & -0.25 & 0.804 & . \\
\hline cnae_27 & 0.08621 & 0.1092 & -8.8 & 0.6 & -0.72 & 0.472 & . \\
\hline cnae_28 & 0.06897 & 0.04598 & 8.7 & -47.2 & 0.92 & 0.358 & . \\
\hline cnae_29 & 0.0977 & 0.12069 & -9 & 62.3 & -0.69 & 0.493 & . \\
\hline cnae_30 & 0.02299 & 0.01149 & 9.5 & 24.2 & 0.82 & 0.412 & . \\
\hline cnae_31 & 0.02874 & 0.03448 & -3.6 & -31.6 & -0.31 & 0.76 & . \\
\hline cnae_32 & 0.01724 & 0.02874 & -7.9 & -19.7 & -0.71 & 0.476 & . \\
\hline cnae_33 & 0 & 0 & 0 & 100 & . & . & . \\
\hline cnae_35 & 0 & 0 & . & . & . & . & . \\
\hline cnae_38 & 0 & 0 & . & . & . & . & . \\
\hline cnae_50 & 0 & 0 & 0 & 100 & . & . & . \\
\hline cnae_58 & 0 & 0 & 0 & 100 & . & . & . \\
\hline cnae_59 & 0 & 0 & . & . & . & . & . \\
\hline cnae_60 & 0 & 0 & 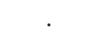 & . & . & . & . \\
\hline cnae_61 & 0.01149 & 0.02299 & -11.2 & -858.3 & -0.82 & 0.412 & . \\
\hline cnae_62 & 0.08621 & 0.05747 & 10.2 & -578.7 & 1.04 & 0.301 & . \\
\hline cnae_63 & 0 & 0 & 0 & 100 & . & & . \\
\hline cnae_71 & 0.00575 & 0 & 9.4 & -51.5 & 1 & 0.318 & . \\
\hline cnae_72 & 0 & 0 & 0 & 100 & . & . & . \\
\hline cnae_81 & 0 & 0 & 0 & 100 & . & . & . \\
\hline cnae_89 & 0.00575 & 0.00575 & 0 & 100 & 0 & 1 & . \\
\hline cnae_91 & 0.00575 & 0 & 10.1 & -22.1 & 1 & 0.318 & . \\
\hline cnae_99 & 0 & 0 & & & & & . \\
\hline Sample & Ps R2 & LR chi2 & $\mathrm{p}>$ chi2 & MeanBias & MedBias & & \\
\hline Unmatched & 0.158 & 155.1 & 0 & 14.4 & 8.9 & & \\
\hline Matched & 0.05 & 23.79 & 0.904 & 6.5 & 5.4 & & \\
\hline
\end{tabular}


TABLE A.7

Results of the means test for the estimated propensity score.

Broad classification: type of innovation

\begin{tabular}{|c|c|c|c|c|c|c|c|}
\hline \multirow{2}{*}{ Covariate } & \multicolumn{2}{|c|}{ Mean } & \multirow{2}{*}{ \%bias } & \multirow{2}{*}{$\begin{array}{c}\% \text { reduct } \\
\text { |bias }\end{array}$} & \multicolumn{2}{|c|}{ t-test } & \multirow{2}{*}{$\begin{array}{l}\mathrm{V}(\mathrm{T}) / \\
\mathrm{V}(\mathrm{C})^{\mathrm{b}}\end{array}$} \\
\hline & Treated & Control & & & $t$ & $\mathrm{p}>\mathbf{t} \mid$ & \\
\hline revenue & $9.90 \mathrm{E}+05$ & $1.10 \mathrm{E}+06$ & -3.7 & 93.6 & -0.3 & 0.763 & 0.56 \\
\hline personnel & 6.8242 & 6.8727 & -3.3 & 97.8 & -0.27 & 0.787 & 0.82 \\
\hline age & 29.456 & 28.669 & 5.9 & 74.9 & 0.46 & 0.649 & 1.15 \\
\hline nac_control & 0.632 & 0.70824 & -20.1 & 74.7 & -1.28 & 0.201 & . \\
\hline for_control & 0.424 & 0.33931 & 21.2 & 73.9 & 1.38 & 0.169 & . \\
\hline rd_cont & 0.808 & 0.81137 & -0.9 & 99.4 & -0.07 & 0.946 & . \\
\hline group & 0.424 & 0.4555 & -7.4 & 89.2 & -0.5 & 0.618 & . \\
\hline imp & 0.96 & 0.94596 & 3.6 & 97.5 & 0.52 & 0.602 & . \\
\hline $\exp$ & 0.912 & 0.90369 & 2 & 98.5 & 0.23 & 0.821 & . \\
\hline for_market & 0.112 & 0.10407 & 3 & 87.7 & 0.2 & 0.841 & . \\
\hline dummyN & 0.04 & 0.0391 & 0.5 & -1190 & 0.04 & 0.971 & . \\
\hline dummyNE & 0.032 & 0.02683 & 1.9 & 88.7 & 0.24 & 0.81 & . \\
\hline dummySE & 0.104 & 0.08586 & 5.2 & 73.5 & 0.49 & 0.626 & . \\
\hline dummySa & 0.4 & 0.45979 & -12.8 & 38.8 & -0.95 & 0.342 & . \\
\hline dummyCO & 0 & 0 & 0 & 100 & . & & . \\
\hline cnae_10 & 0.12 & 0.17326 & -17.1 & -552.1 & -1.19 & 0.236 & . \\
\hline cnae_11 & 0.008 & 0.0097 & -1.4 & 52.8 & -0.14 & 0.887 & . \\
\hline cnae_12 & 0.008 & 0.00294 & 7.9 & -62.5 & 0.54 & 0.59 & . \\
\hline cnae_13 & 0.016 & 0.01823 & -1.4 & 92.3 & -0.14 & 0.892 & . \\
\hline cnae_14 & 0 & 0 & 0 & 100 & & . & . \\
\hline cnae_15 & 0.008 & 0.00645 & 1 & 94.4 & 0.14 & 0.885 & . \\
\hline cnae_16 & 0 & 0 & 0 & 100 & . & . & . \\
\hline cnae_17 & 0.008 & 0.00995 & -1.5 & 85.1 & -0.16 & 0.871 & . \\
\hline cnae_18 & 0 & 0 & 0 & 100 & . & . & . \\
\hline cnae_19 & 0 & 0 & 0 & 100 & . & . & . \\
\hline cnae_20 & 0.064 & 0.06038 & 1.5 & 89.9 & 0.12 & 0.906 & . \\
\hline cnae_21 & 0.048 & 0.03805 & 6.3 & 64.5 & 0.39 & 0.7 & . \\
\hline cnae_22 & 0.04 & 0.04707 & -3.3 & 72.8 & -0.27 & 0.785 & . \\
\hline cnae_23 & 0.024 & 0.0248 & -0.4 & 97.5 & -0.04 & 0.968 & . \\
\hline cnae_24 & 0.04 & 0.03176 & 4.7 & 46.1 & 0.35 & 0.727 & . \\
\hline cnae_25 & 0.04 & 0.048 & -3.6 & 83 & -0.31 & 0.759 & . \\
\hline cnae_26 & 0.128 & 0.1089 & 7.8 & 73.4 & 0.47 & 0.642 & . \\
\hline cnae_27 & 0.048 & 0.04508 & 1.5 & 84.4 & 0.11 & 0.913 & . \\
\hline cnae_28 & 0.144 & 0.15515 & -3.7 & 84.8 & -0.25 & 0.806 & . \\
\hline cnae_29 & 0.168 & 0.14836 & 6.8 & 84.3 & 0.42 & 0.672 & . \\
\hline cnae_30 & 0.016 & 0.00771 & 8.2 & -277.5 & 0.6 & 0.547 & . \\
\hline cnae_31 & 0.016 & 0.01454 & 0.9 & 92.4 & 0.09 & 0.926 & . \\
\hline cnae_32 & 0.024 & 0.01948 & 2.9 & 21.4 & 0.24 & 0.807 & . \\
\hline cnae_33 & 0 & 0 & 0 & 100 & . & . & . \\
\hline cnae_35 & 0 & 0 & 0 & 100 & . & . & . \\
\hline cnae_38 & 0 & 0 & . & & . & . & . \\
\hline cnae_50 & 0 & 0 & 0 & 100 & . & . & . \\
\hline cnae_58 & 0 & 0 & 0 & 100 & . & . & . \\
\hline cnae_59 & 0 & 0 & 0 & 100 & . & . & . \\
\hline cnae_60 & 0 & 0 & 0 & 100 & . & . & . \\
\hline cnae_61 & 0.008 & 0.00941 & -1.4 & 49.6 & -0.12 & 0.905 & . \\
\hline cnae_62 & 0.016 & 0.0175 & -1 & 91.3 & -0.09 & 0.927 & . \\
\hline cnae_63 & 0 & 0 & 0 & 100 & . & & . \\
\hline cnae_71 & 0.008 & 0.0033 & 3.7 & 79.2 & 0.49 & 0.621 & . \\
\hline cnae_72 & 0 & 0 & 0 & 100 & . & . & . \\
\hline cnae_81 & 0 & 0 & 0 & 100 & . & . & . \\
\hline cnae_89 & 0 & 0 & 0 & 100 & . & . & . \\
\hline cnae_91 & 0 & 0 & 0 & 100 & . & . & . \\
\hline cnae_99 & 0 & 0 & 0 & 100 & . & 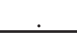 & . \\
\hline Sample & Ps R2 & LR chi2 & $\mathrm{p}>\mathrm{chi} 2$ & MeanBias & MedBias & & \\
\hline Unmatched & 0.369 & 516.5 & 0 & 28.5 & 16.5 & & \\
\hline Matched & 0.019 & 6.74 & 1 & 3.4 & 1.5 & & \\
\hline
\end{tabular}


TABLE A.8

Estimated policy impact: robustness checks results

\begin{tabular}{|c|c|c|c|c|c|}
\hline \multirow[b]{2}{*}{ Broad classification } & \multirow{2}{*}{$\begin{array}{l}\text { Outcome } \\
\text { variable }\end{array}$} & \multicolumn{4}{|c|}{ Estimated ATT - Robustness checks } \\
\hline & & $\begin{array}{c}\text { kernel } \\
\text { matchinga }\end{array}$ & $\begin{array}{c}\text { radius } \\
\text { matchingb }\end{array}$ & $\begin{array}{l}\text { Log-linear- } \\
\text { izedc }\end{array}$ & $\begin{array}{c}\text { SUR and } \\
\text { lineard }\end{array}$ \\
\hline \multirow{7}{*}{$\begin{array}{c}\text { Innovative activities } \\
\text { expenditures }\end{array}$} & rd_tot & $\begin{array}{l}835.45^{* * *} \\
(220.77)\end{array}$ & $\begin{array}{l}543.37^{* *} \\
(223.69)\end{array}$ & $\begin{array}{l}0.0014^{* * *} \\
(0.0005)\end{array}$ & $\begin{array}{l}1186.5^{* * *} \\
(342.61)\end{array}$ \\
\hline & knowledge & $\begin{array}{l}-154.05^{* * *} \\
(59.35)\end{array}$ & $\begin{array}{l}-138.07^{* *} \\
(60.94)\end{array}$ & $\begin{array}{l}-0.0027^{* *} \\
(0.0013)\end{array}$ & $\begin{array}{l}-180.23^{* *} \\
(80.01)\end{array}$ \\
\hline & software & $\begin{array}{l}-80.28 \\
(58.18)\end{array}$ & $\begin{array}{l}-45.51 \\
(60.4)\end{array}$ & $\begin{array}{l}0.0003 \\
(0.0006)\end{array}$ & $\begin{array}{l}51.58 \\
(142.1)\end{array}$ \\
\hline & machinery & $\begin{array}{l}-19.69 \\
(222.79)\end{array}$ & $\begin{array}{l}-41.36 \\
(230.18)\end{array}$ & $\begin{array}{l}-0.0007 \\
(0.0006)\end{array}$ & $\begin{array}{l}-501.3 \\
(303.35)\end{array}$ \\
\hline & training & $\begin{array}{l}66.27 \\
(45.33)\end{array}$ & $\begin{array}{l}89.11^{*} \\
(46.58)\end{array}$ & $\begin{array}{l}0.0002 \\
(0.0008)\end{array}$ & $\begin{array}{l}29.36 \\
(42.23)\end{array}$ \\
\hline & intro & $\begin{array}{l}-198.03 \\
(123.74)\end{array}$ & $\begin{array}{l}-146 \\
(127.48)\end{array}$ & $\begin{array}{l}-0.0011^{* *} \\
(0.0005)\end{array}$ & $\begin{array}{l}-320.13^{*} \\
(177.24)\end{array}$ \\
\hline & project & $\begin{array}{l}149.01^{*} \\
(84.67)\end{array}$ & $\begin{array}{l}85.58 \\
(86.68) \\
\end{array}$ & $\begin{array}{l}0 \\
(0.0006)\end{array}$ & $\begin{array}{l}-33.42 \\
(116.69)\end{array}$ \\
\hline \multirow{5}{*}{ Educational level } & phd & $\begin{array}{l}-0.11 \\
(0.12)\end{array}$ & $\begin{array}{l}-0.12 \\
(0.12)\end{array}$ & $\begin{array}{l}-0.0015 \\
(0.0031)\end{array}$ & $\begin{array}{l}-0.06 \\
(0.13)\end{array}$ \\
\hline & master & $\begin{array}{l}-0.06 \\
(0.18)\end{array}$ & $\begin{array}{l}-0.04 \\
(0.18)\end{array}$ & $\begin{array}{l}-0.0002 \\
(0.0053)\end{array}$ & $\begin{array}{l}-0.05 \\
(0.23)\end{array}$ \\
\hline & undergrad & $\begin{array}{l}1.78 \\
(1.31)\end{array}$ & $\begin{array}{l}1.87 \\
(1.33)\end{array}$ & $\begin{array}{l}0.0134^{* *} \\
(0.0065)\end{array}$ & $\begin{array}{l}3.38^{* *} \\
(1.4)\end{array}$ \\
\hline & high & $\begin{array}{l}0.98 \\
(1.08)\end{array}$ & $\begin{array}{l}1.13 \\
(1.1)\end{array}$ & $\begin{array}{l}0.0019 \\
(0.0024)\end{array}$ & $\begin{array}{l}1.51 \\
(1.38)\end{array}$ \\
\hline & other & $\begin{array}{l}0.9^{*} \\
(0.48)\end{array}$ & $\begin{array}{l}0.9^{*} \\
(0.5)\end{array}$ & $\begin{array}{l}0.0025 \\
(0.0019)\end{array}$ & $\begin{array}{l}1.47 \\
(1.18)\end{array}$ \\
\hline \multirow{3}{*}{ Type of innovation } & product & $\begin{array}{l}-0.02 \\
(0.04)\end{array}$ & $\begin{array}{l}0.02 \\
(0.04)\end{array}$ & & $\begin{array}{l}0 \\
(0.05)\end{array}$ \\
\hline & project & $\begin{array}{l}-0.04 \\
(0.04)\end{array}$ & $\begin{array}{l}-0.03 \\
(0.04)\end{array}$ & & $\begin{array}{l}-0.03 \\
(0.05)\end{array}$ \\
\hline & both & $\begin{array}{l}0.06 \\
(0.05)\end{array}$ & $\begin{array}{l}0.003 \\
(0.05)\end{array}$ & & $\begin{array}{l}0.03 \\
(0.07)\end{array}$ \\
\hline
\end{tabular}

Standard errors in parenthesis. ${ }^{*} \mathrm{p}<.10 ;{ }^{* *} \mathrm{p}<.05 ;{ }^{* * *} \mathrm{p}<.01$.

${ }^{a}$ Matching algorithm: kernel. Standard error estimated by 100 bootstrap iterations.

${ }^{\mathrm{b}}$ Matching algorithm: radius within caliper ( $20 \%$ of the standard deviation of the propensity score). Standard error estimated by 100 bootstrap iterations.

c Continuous variables were log-linearized according to the following transformation equation: $\ln \_x \_i=\ln \left(x \_i+x \_m i n+1\right)$; where (xmin) means the minimum value observed for $(\mathrm{xi})$ in the sample. Matching algorithm: nearest neighbor. Standard error estimated according to Abadie and Imbens (2006).

${ }^{d}$ Matching algorithm: nearest neighbor. Estimated effect (ATT) is the value of the coefficient of the treatment dummy independent variable. For continuous dependent variables, analysis was performed through a seemingly unrelated regressions estimator, and in the case of binary dependent variables a linear regression was applied. In both cases, only observations used in the main propensity score model were used, weighted according to the number of repetitions for non-treated units. 
TABLE A.9

Results of the sensitivity analysis of hidden bias due to omitted variables (Rosenbaum bounds)

\begin{tabular}{|c|c|c|c|c|c|c|c|}
\hline $\begin{array}{c}\text { Outcome } \\
\text { variable }\end{array}$ & $\Gamma$ & sig+ & sig- & t-hat+ & t-hat- & CI+ & CI- \\
\hline \multirow[t]{11}{*}{$r d \_t o t$} & 1 & 0.0011 & 0.0011 & 451.0500 & 451.0500 & 154.1740 & 842.2120 \\
\hline & 1.1 & 0.0057 & 0.0001 & 359.0780 & 552.5000 & 67.5165 & 959.5570 \\
\hline & 1.2 & 0.0208 & 0.0000 & 287.1750 & 656.8300 & 1.9385 & 1078.6900 \\
\hline & 1.3 & 0.0562 & 0.0000 & 218.0360 & 744.9500 & -42.0000 & 1187.2800 \\
\hline & 1.4 & 0.1205 & 0.0000 & 158.5370 & 835.5930 & -110.6250 & 1306.3300 \\
\hline & 1.5 & 0.2152 & 0.0000 & 100.0000 & 907.1880 & -190.3430 & 1403.1600 \\
\hline & 1.6 & 0.3337 & 0.0000 & 44.2325 & 999.7590 & -300.0000 & 1503.0400 \\
\hline & 1.7 & 0.4629 & 0.0000 & 1.9385 & 1077.0000 & -375.6720 & 1619.3800 \\
\hline & 1.8 & 0.5886 & 0.0000 & -22.0615 & 1138.4200 & -441.3260 & 1698.1000 \\
\hline & 1.9 & 0.6999 & 0.0000 & -57.5000 & 1236.2300 & -512.4920 & 1823.1700 \\
\hline & 2 & 0.7908 & 0.0000 & -109.5000 & 1303.8300 & -571.3720 & 1922.6800 \\
\hline \multirow[t]{11}{*}{ knowledge } & 1 & 0.0011 & 0.0011 & 0.0006 & 0.0006 & 0.0002 & 0.0011 \\
\hline & 1.1 & 0.0058 & 0.0001 & 0.0004 & 0.0007 & 0.0001 & 0.0012 \\
\hline & 1.2 & 0.0210 & 0.0000 & 0.0004 & 0.0008 & 0.0000 & 0.0013 \\
\hline & 1.3 & 0.0567 & 0.0000 & 0.0003 & 0.0009 & -0.0001 & 0.0015 \\
\hline & 1.4 & 0.1212 & 0.0000 & 0.0002 & 0.0010 & -0.0001 & 0.0016 \\
\hline & 1.5 & 0.2163 & 0.0000 & 0.0001 & 0.0011 & -0.0002 & 0.0018 \\
\hline & 1.6 & 0.3351 & 0.0000 & 0.0001 & 0.0013 & -0.0004 & 0.0019 \\
\hline & 1.7 & 0.4644 & 0.0000 & 0.0000 & 0.0013 & -0.0005 & 0.0020 \\
\hline & 1.8 & 0.5901 & 0.0000 & 0.0000 & 0.0014 & -0.0006 & 0.0021 \\
\hline & 1.9 & 0.7012 & 0.0000 & -0.0001 & 0.0015 & -0.0006 & 0.0023 \\
\hline & 2 & 0.7919 & 0.0000 & -0.0001 & 0.0016 & -0.0007 & 0.0024 \\
\hline \multirow[t]{11}{*}{ intro } & 1 & 0.0793 & 0.0793 & -2.3267 & -2.3267 & -6.2035 & 0.7197 \\
\hline & 1.1 & 0.0289 & 0.1771 & -3.1240 & -1.4738 & -7.4549 & 1.4015 \\
\hline & 1.2 & 0.0095 & 0.3131 & -3.9962 & -0.6686 & -8.4748 & 2.1775 \\
\hline & 1.3 & 0.0029 & 0.4666 & -4.7354 & -0.0634 & -9.5999 & 2.9312 \\
\hline & 1.4 & 0.0008 & 0.6139 & -5.6807 & 0.2720 & -10.6116 & 3.7912 \\
\hline & 1.5 & 0.0002 & 0.7381 & -6.3769 & 0.7588 & -11.6235 & 4.4780 \\
\hline & 1.6 & 0.0001 & 0.8324 & -7.2433 & 1.3005 & -12.5934 & 5.1309 \\
\hline & 1.7 & 0.0000 & 0.8981 & -7.8894 & 1.6522 & -13.3530 & 5.8128 \\
\hline & 1.8 & 0.0000 & 0.9408 & -8.5494 & 2.2328 & -14.1341 & 6.6436 \\
\hline & 1.9 & 0.0000 & 0.9670 & -9.2593 & 2.7492 & -14.7766 & 7.3947 \\
\hline & 2 & 0.0000 & 0.9822 & -9.9878 & 3.1584 & -15.5141 & 8.3672 \\
\hline \multirow[t]{11}{*}{ undergrad } & 1 & 0.0124 & 0.0124 & 2.1250 & 2.1250 & 0.2500 & 4.1000 \\
\hline & 1.1 & 0.0445 & 0.0026 & 1.6000 & 2.6500 & -0.3000 & 4.6750 \\
\hline & 1.2 & 0.1135 & 0.0005 & 1.1000 & 3.1500 & -0.7500 & 5.2500 \\
\hline & 1.3 & 0.2244 & 0.0001 & 0.7300 & 3.6000 & -1.2000 & 5.7500 \\
\hline & 1.4 & 0.3665 & 0.0000 & 0.3000 & 4.0500 & -1.6500 & 6.2250 \\
\hline & 1.5 & 0.5183 & 0.0000 & -0.0175 & 4.4250 & -2.0000 & 6.6500 \\
\hline & 1.6 & 0.6583 & 0.0000 & -0.4500 & 4.8350 & -2.4500 & 7.0800 \\
\hline & 1.7 & 0.7729 & 0.0000 & -0.7500 & 5.2250 & -2.8000 & 7.5500 \\
\hline & 1.8 & 0.8577 & 0.0000 & -1.0250 & 5.5250 & -3.0750 & 8.0000 \\
\hline & 1.9 & 0.9155 & 0.0000 & -1.3500 & 5.8600 & -3.4000 & 8.3000 \\
\hline & 2 & 0.9521 & 0.0000 & -1.6000 & 6.1750 & -3.7000 & 8.7500 \\
\hline
\end{tabular}

* gamma - log odds of differential assignment due to unobserved factors; sig+ - upper bound significance level; sig- - lower bound significance level; t-hat+ - upper bound Hodges-Lehmann point estimate; t-hat- - lower bound Hodges-Lehmann point estimate; CI+ - upper bound confidence interval $(a=.95)$; CI- - lower bound confidence interval $(a=.95)$. 
